\title{
Role of Escherichia coli RpoS, LexA and $H-N S$ global regulators in metabolism and survival under aerobic, phosphate-starvation conditions
}

\author{
Fabien Gérard, Anna-Maria Dri and Patrice L. Moreau
}

Author for correspondence: Patrice L. Moreau. Tel: +334911643 53. Fax: +33491718914. e-mail: moreau@ibsm.cnrs-mrs.fr

Centre National de la Recherche Scientifique, Laboratoire de Chimie Bactérienne, 31 chemin Joseph Aiguier, 13402 Marseille cedex 20, France
It has been suggested that Escherichia coli can resist aerobic, glucosestarvation conditions by switching rapidly from an aerobic to a fermentative metabolism, thereby preventing the production by the respiratory chain of reactive oxygen species (ROS) that can damage cellular constituents. In contrast, it has been reported that $E$. coli cannot resist aerobic, phosphate $\left(P_{i}\right)$ starvation conditions, probably because of the maintenance of an aerobic metabolism and the continuous production of ROS. This paper presents evidence that $E$. coli cells starved for $P_{i}$ under aerobic conditions indeed maintain an active aerobic metabolism for about $3 \mathrm{~d}$, which allows the complete degradation of exogenous nutrients such as arginine (metabolized probably to putrescine via the SpeA-initiated pathway) and glucose (metabolized notably to acetate), but cell viability is not significantly affected because of the protection afforded against ROS through the expression of the RpoS and LexA regulons. The involvement of the LexA-controlled RuvAB and RecA proteins with the RecG and RecBCD proteins in metabolism and cell viability implies that DNA double-strand breaks (DSB), and thus hydroxyl radicals that normally generate this type of damage, are produced in $P_{i}-$-starved cells. It is shown that induction of the LexA regulon, which helps protect $P_{i}-$ starved cells, is totally prevented by introduction of a recB mutation, which indicates that DSB are actually the main DNA lesion generated in $P_{i}$-starved cells. The requirement of RpoS for survival of cells starved for $P_{i}$ may thus be explained by the role played by various RpoS-controlled gene products such as KatE, KatG and Dps in the protection of DNA against ROS. In the same light, the degradation of arginine and threonine may be accounted for by the synthesis of polyamines (putrescine and spermidine) that protect nucleic acids from ROS. Besides LexA and RpoS, a third global regulator, the nucleoidassociated protein $\mathrm{H}-\mathrm{NS}$, is also shown to play a key role in $\mathrm{P}_{\mathrm{i}}$-starved cells. Through a modulation of the metabolism during $P_{i}$ starvation, H-NS may perform two complementary tasks: it helps maintain a rapid metabolism of glucose and arginine, probably by favouring the activity of aerobic enzymes such as the NAD-dependent pyruvate dehydrogenase complex, and it may enhance the cellular defences against ROS which are then produced by increasing RpoS activity via the synthesis of acetate and presumably homoserine lactone.

Keywords: H-NS, LexA, phosphate starvation, reactive oxygen species, RpoS 


\section{INTRODUCTION}

Escherichia coli is a facultative anaerobe which is able to obtain energy through aerobic respiration, anaerobic respiration, or fermentation. During the exponential phase of growth under aerobic conditions, aerobic respiration is preferred to anaerobic respiration or fermentation because it is the most energetically favourable process (Guest, 1992; Gennis \& Stewart, 1996). Such a preference for oxygen as terminal electron acceptor has an inherent drawback: the generation by the respiratory chain of the toxic superoxide anion radical $\left(\mathrm{O}_{2}^{--}\right)$. Superoxide and the resulting other reactive oxygen species (ROS) such as hydrogen peroxide $\left(\mathrm{H}_{2} \mathrm{O}_{2}\right)$ and the hydroxyl radical $\left(\mathrm{HO}^{\circ}\right)$ can damage all cellular components, lipids, proteins and nucleic acids (González-Flecha \& Demple, 1995; Lynch \& Lin, 1996; Vaughan, 1997). In the case of DNA oxidation, it has been suggested that iron released from dehydratases by superoxide, and adventitiously deposited on the surface of DNA, can catalyse the conversion of $\mathrm{H}_{2} \mathrm{O}_{2}$ into hydroxyl radicals that readily attack the adjacent sugar and base moieties (Keyer \& Imlay, 1996). Damage of DNA bases produces a wide variety of alterations that can give rise to base-substitution mutations following erroneous replication of modified bases (Henle \& Linn, 1997; Kreutzer \& Essigmann, 1998). Damage of DNA sugar generates essentially single-strand breaks (Henle \& Linn, 1997) that can produce potentially lethal double-strand breaks (DSB) after collapsing the replication fork (Asai et al., 1994; Cox, 1997). DSB can also result from the chance occurrence of overlapping singlestrand breaks in the complementary strands of a nonreplicating DNA molecule (Rupp, 1996; Chol Ha et al., 1998; Henle et al., 1999).

Cells are efficiently protected against ROS attack by an array of protective mechanisms. For example, E. coli possesses superoxide dismutases (SodA, SodB), catalases (KatE, KatG), peroxidases (AhpCF, Tpx), DNA-protecting compounds (Dps, polyamines), and DNA-repair enzymes specific for either oxidized bases (XthA, Nfo, Nth and MutMTY for oxidized purines) or DSB (RecBCD, RecA, RecG, RuvABC) (Demple \& Harrison, 1994; Lynch \& Lin, 1996; Rupp, 1996; Henle \& Linn, 1997; Chol $\mathrm{Ha}$ et al., 1998). Many of the genes implicated in the defence against ROS are inducible and belong to regulons that enable bacteria to cope with various stresses: the SoxRS regulon, including $\operatorname{sod} A$ and $n f o$, which responds to redox-cycling drugs; the OxyR regulon, including kat $G$ and $d p s$, which is induced in actively growing cells in response to $\mathrm{H}_{2} \mathrm{O}_{2}$-mediated oxidation; the $\operatorname{RpoS}\left(\sigma^{\mathrm{s}}\right)$ regulon, including also kat $G$ and $d p s$, which is induced when bacteria enter stationary phase; and the LexA regulon, including rec $A$ and $r u v A B$, which is induced by DNA damage (Sak et al., 1989; Altuvia et al., 1994; Hengge-Aronis, 1996; Walker, 1996; González-Flecha \& Demple, 1997; Gort \& Imlay, 1998).

Recent data suggest that, under starvation conditions, $E$. coli can abandon its normal preference for aerobic metabolism in order to avoid the production of ROS. Indeed, when bacteria grown under aerobic conditions are starved for glucose, the pattern of protein synthesis is immediately changed in a manner that is reminiscent of a shift from aerobiosis to anaerobiosis (Nyström, 1994). For example, fermentative enzymes such as the pyruvate formate-lyase (Pf) (Böck \& Sawers, 1996) are produced in increased amounts, whereas aerobic enzymes such as the NAD-dependent lipoamide dehydrogenase subunit (Lpd) present notably in the pyruvate dehydrogenase complex (PDH) (Quail et al., 1994) are produced in decreased amounts (Nyström, 1994). These changes in protein synthesis are thought to help E. coli to survive prolonged starvation (Nyström et al., 1996). Two lines of evidence suggest, however, that E. coli cells starved for phospate $\left(\mathrm{P}_{\mathrm{i}}\right)$ maintain an aerobic metabolism. First, at the onset of $P_{i}$ starvation, the rate of synthesis of the AceF subunit of the aerobic enzyme $\mathrm{PDH}$ (AceEF-Ldp) is not significantly affected, while the rate of synthesis of the fermentative enzyme Pfl is strongly reduced (VanBogelen et al., 1996). Second, Davis et al. (1986) have shown that E. coli strain D10 could not survive under aerobic $P_{\mathrm{i}}$-starvation conditions (viability was reduced to $10^{-5}$ by about $3 \mathrm{~d}$ of incubation) because of an extensive degradation of ribosomes. Nyström et al. (1996) have suggested that such an unrestrained degradation of ribosomes could result from an unchecked respiratory activity generating high levels of ROS. The possibility that $E$. coli cells starved for $P_{i}$ may suffer more oxidative damage than cells starved for glucose could help explain our previous finding that DNA-repair genes that belong to the LexA regulon are induced when cells are starved for $P_{i}$, but not when they are starved for glucose (Dri \& Moreau, 1993). For unknown reasons, induction of the LexA regulon is then dependent upon the nucleoid-associated protein H-NS (Dri \& Moreau, 1993), which normally helps E. coli to adapt to stressful environmental conditions (Atlung \& Ingmer, 1997).

In this report, we present evidence that E. coli cells starved for $P_{i}$ under aerobic conditions maintain an active aerobic metabolism for several days, which results in dramatic changes in the composition of the culture medium. However, cell viability is not particularly affected because of the protection afforded against ROS by the expression of the RpoS and LexA regulons, and probably by the synthesis of polyamines. We also show that $\mathrm{H}-\mathrm{NS}$ plays a key role in co-ordinating metabolic and protective processes in $\mathrm{P}_{\mathbf{i}}$-starved cells.

\section{METHODS}

Bacterial strains. These are listed in Table $1 . E$. coli strain ENZ361 is a derivative of strain AB1157 (Bachmann, 1996). It should be noted that these strains, which carry the $t h r-1$ (Am) mutation, are still $\mathrm{Thr}^{-}$despite the presence of the weak amber suppressor supE44 ( $\ln$ V44) (Mount \& Kosel, 1975; Eggertsson \& Söll, 1988). In contrast, it appeared that the rpoS(Am) mutation carried by strain AB1157 (Visick \& Clarke, 1997) and, thus, by strain ENZ361 is partially suppressed by supE44, as suggested by the use of the catalase 
Table 1. Escherichia coli $\mathrm{K}-12$ strains

\begin{tabular}{|c|c|c|}
\hline Strain & Genotype & Source \\
\hline ENZ361 & $\begin{array}{l}\mathrm{F}^{-} \text {thr-1(Am) ara-14 leuB6 } \Delta(\mathrm{argF}-\mathrm{lac}) U 169 \mathrm{ts} x-33 \mathrm{glnV} 44 \text { (supE44) galK2 sulA211 } \mathrm{rac}^{-} \\
\text {hisG4(Oc) rfbD1 mgl-51 rpoS396(Am) rpsL31 kdgK51 xyl-5 mtl-1 argE3(Oc) thi-1 }\end{array}$ & Dri \& Moreau (1993) \\
\hline ENZ376 & $\lambda c I I n d^{-}$psulA::lacZ lysogen of ENZ361 & Dri \& Moreau (1993) \\
\hline ENZ408 & As ENZ361 but hns-205:: $\operatorname{Tn} 10$ & Higgins et al. $(1988)^{*}$ \\
\hline ENZ409 & As ENZ376 but hns-205:: $\operatorname{Tn} 10$ & Dri \& Moreau (1993) \\
\hline ENZ616 & As ENZ361 but lexA71:: Tn5(Def) & Krueger et al. $(1983)^{*}$ \\
\hline ENZ618 & As ENZ361 but $\Delta(s r l r e c A) 306:: \operatorname{Tn} 10$ & Willis et al. $(1981)^{*}$ \\
\hline ENZ625 & As ENZ361 but recG263::kan & Mandal et al. $(1993)^{*}$ \\
\hline ENZ644 & As ENZ361 but recO1504:: $\operatorname{Tn} 5$ recF332: : $\operatorname{Tn} 3$ & $\begin{array}{l}\text { Kolodner et al. }(1985) \\
\text { Blanar } \text { et al. }(1984)^{*}\end{array}$ \\
\hline ENZ678 & As ENIZ361 but recB268:: Tn10 & Lloyd et al. $(1987)^{*}$ \\
\hline ENZ679 & As ENZ376 but recB268:: $\operatorname{Tn} 10$ & Lloyd et al. (1987)* \\
\hline ENZ701 & As ENZ361 but malB45 zja-505:: Tn10 lexA3(Ind $\left.{ }^{-}\right)$ & $\begin{array}{l}\text { Ossanna \& Mount } \\
(1989)^{*}\end{array}$ \\
\hline ENZ702 & As ENZ361 but ruvA60:: $\operatorname{Tn} 10$ & Sharples et al. $(1990)^{*}$ \\
\hline ENZ720 & As ENZ361 but sup-720 & Spontaneous suppressor \\
\hline ENZ725 & As ENZ361 but srl-300:: Tn10 & Willis et al. (1981)" \\
\hline ENZ766 & As ENZ361 but rpoS359::Tn10 (null) & $\begin{array}{l}\text { Lange \& Hengge-Aronis } \\
(1991)^{*}\end{array}$ \\
\hline ENZ768 & As ENZ361 but bns::neo & Yamada et al. $(1991)^{*}$ \\
\hline ENZ833 & As ENZ361 but ruvA60:: Tn10 recG263::kan & $\begin{array}{l}\text { Sharples et al. }(1990) \text {; } \\
\text { Mandal et al. }(1993)^{*}\end{array}$ \\
\hline ENZ840 & As ENZ720 (sup-720) but nadA57::Tn10 & Singer et al. (1989)" \\
\hline ENZ849 & As ENZ720 (sup-720) but srl-300:: $\operatorname{Tn} 10$ & Willis et al. $(1981)^{*}$ \\
\hline ENZ858 & As ENZ361 but $\mathrm{Arg}^{+}$ & Spontaneous revertant \\
\hline ENZ862 & As ENZ858 but $\mathrm{Thr}^{+}$ & Spontaneous revertant \\
\hline ENZ868 & As ENZ862 but $\mathrm{His}^{+}$ & Spontaneous revertant \\
\hline ENZ875 & As ENZ858 $\left(\mathrm{Arg}^{+}\right)$but $s r l-300:: \operatorname{Tn} 10$ & Willis et al. $(1981)^{*}$ \\
\hline ENZ878 & As ENZ868 $\left(\mathrm{Arg}^{+} \mathrm{Thr}^{+} \mathrm{His}^{+}\right)$but srl-300::Tn10 & Willis et al. $(1981)^{*}$ \\
\hline ENZ885 & As ENZ361 but adiA::MudI1734(kan) & $\begin{array}{l}\text { Stim-Herndon et al. } \\
(1996)^{*}\end{array}$ \\
\hline ENZ897 & As ENZ361 but nadA57:: Tn10 sup-720 & ENZ840* \\
\hline ENZ898 & As ENZ361 but nadA::Tn10 lysT(SuUAA/G) (supG) & Prather et al. $(1983)^{*}$ \\
\hline ENZ963 & As ENZ862 $\left(\mathrm{Arg}^{+} \mathrm{Thr}^{+}\right)$but $s r l-300:: \operatorname{Tn} 10$ & Willis et al. $(1981)^{*}$ \\
\hline ENZ1214 & As ENZ361 but astB::kan & Schneider et al. (1998)* \\
\hline ENZ1215 & As ENZ361 but astC::kan & Schneider et al. $(1998)^{*}$ \\
\hline MG1655 & $\mathrm{F}^{-} r p b-1 r f b-50$ & $\begin{array}{l}\text { M. Cashel, NIH, } \\
\text { Bethesda, MD, USA }\end{array}$ \\
\hline
\end{tabular}

* The source indicates the origin of the strain from which the new mutation was obtained.

assay $\left(\mathrm{H}_{2} \mathrm{O}_{2} \rightarrow \mathrm{O}_{2}+\mathrm{H}_{2} \mathrm{O}\right)$ previously employed by Lange \& Hengge-Aronis (1991) and Zambrano et al. (1993) to characterize $r p o S$ mutant strains. In fact, introduction into strain ENZ361 of a null rpoS mutation reduced the level of expression of RpoS-controlled catalases (KatE and KatG), as revealed by an increase in the time required to see the production of $\mathrm{O}_{2}$ from $\mathrm{H}_{2} \mathrm{O}_{2}$ dropped on bacteria, whereas introduction of the $r p o S^{+}$allele from strain MG1655 (Bachmann, 1996) did further enhance the catalase activity, as shown by an increase in the global production of $\mathrm{O}_{2}$, which suggests that strain ENZ361 possesses an intermediate level of RpoS activity between $r p o S$ (null) and $r p o S^{+}$strains. Moreover, subtle but reproducible differences in catalase activity could be observed between strains carrying either rpoS(Am) supE44 mutations (e.g. strain ENZ361) or rpoS(Am) supE44 supG (sup-720) mutations (e.g. strain ENZ720), which supports the idea that these strains possess different RpoSactivity levels, at least in the experimental conditions used to perform the catalase assay (1-d-old bacteria on LB agar medium).

During strain construction, the introduction of mutations was achieved by $\mathrm{P} 1$ transduction (Miller, 1972). The $s r l-300:$ Tn10 mutation from strain JC10244 (Willis et al., 1981) was transduced into various strains to help distinguish bacterial populations in mixed-culture experiments. Localization of the sup-720 locus was accomplished by using conjugational and transductional methods with strains (kindly provided by $B$. Michel) constructed respectively by Wanner (1986) and Singer et al. (1989), which carry the transposon Tn10 at defined positions in the E. coli genome. Backmutants (e.g. $\mathrm{Arg}^{+}$ revertants) were isolated as fast-growing revertants (suppressors often decrease the growth rate) (Eggertsson \& 
Söll, 1988), scored for lack of reversion of nonselected mutations, and tested for their catalase activity to ensure that they behaved as the ENZ361 parental strain.

Media and growth conditions. The minimal medium used for liquid cultures was essentially the MOPS medium described by Neidhardt et al. (1974) containing $86 \mathrm{mM} \mathrm{NaCl}, 9.5 \mathrm{mM}$ $\mathrm{NH}_{4} \mathrm{Cl}, 5 \mathrm{mM} \mathrm{K} \mathrm{HPO}_{4}$ and $20.2 \mathrm{mM}$ glucose $(0.4 \%$, w/v) supplemented with five vitamins $(0.02 \mathrm{mM}$ thiamin, $0.02 \mathrm{mM}$ calcium pantothenate, $0.02 \mathrm{mM}$-aminobenzoic acid, $0.02 \mathrm{mM} p$-hydroxybenzoic acid and $0.02 \mathrm{mM}$ 2,3-dihydroxybenzoic acid; Neidhardt et al., 1977) and six amino acids $(0.4 \mathrm{mM}$ threonine, $0.8 \mathrm{mM}$ leucine, $0.2 \mathrm{mM}$ histidine, $0.4 \mathrm{mM}$ arginine, $0.4 \mathrm{mM}$ isoleucine and $0.6 \mathrm{mM}$ valine; Neidhardt $e t$ al., 1977); the $\mathrm{pH}$ was 7.2. In $\mathrm{P}_{\mathrm{i}}$-limiting medium, the concentration of $\mathrm{K}_{2} \mathrm{HPO}_{4}$ was reduced from 5 to $0 \cdot 1 \mathrm{mM}$, but $9.8 \mathrm{mM} \mathrm{KCl}$ was added to maintain the concentration of potassium as in MOPS medium (Dri \& Moreau, 1993); in glucose-limiting medium, the concentration of glucose was reduced from 0.4 to 0.04 or $0.05 \%(\mathrm{w} / \mathrm{v})$, as indicated. MOPS buffer was MOPS medium deprived of ammonium, phosphate, glucose, amino acids and vitamins. $\mathrm{M9}_{\mathbf{0}}$ buffer consisted of $3 \mathrm{~g} \mathrm{KH}_{2} \mathrm{PO}_{4}, 7.5 \mathrm{~g} \mathrm{Na}_{2} \mathrm{HPO}_{4} .2 \mathrm{H}_{2} \mathrm{O}, 1 \mathrm{~g} \mathrm{NH}_{4} \mathrm{Cl}$ and $5 \mathrm{~g}$ $\mathrm{NaCl}$ per litre. Minimal agar medium (Miller, 1972) was $\mathrm{M9} 9$ supplemented with $1 \mathrm{mM} \mathrm{MgSO}, 0.1 \mathrm{mM} \mathrm{CaCl}_{2}, 0.03 \mathrm{mM}$ thiamin, $0.2 \%(\mathrm{w} / \mathrm{v})$ glucose, amino acids when required $(0.4 \mathrm{mM}$ threonine, $0.8 \mathrm{mM}$ leucine, $0.2 \mathrm{mM}$ histidine, $0.4 \mathrm{mM}$ arginine, $0.4 \mathrm{mM}$ isoleucine, $0.6 \mathrm{mM}$ valine) and $12 \mathrm{~g}$ granulated agar $1^{-1}$. LB agar medium (Miller, 1972; Difco) contained $10 \mathrm{~g}$ Bacto tryptone, $5 \mathrm{~g}$ Bacto yeast extract, $10 \mathrm{~g} \mathrm{NaCl}$ and $15 \mathrm{~g}$ Bacto agar $\mathrm{l}^{-1}$. Media were supplemented with $10 \mu \mathrm{M}$ niacinamide for growing nadA transductants. Tetracycline (Tc) was used at $12 \mu \mathrm{g} \mathrm{ml}^{-1}$. All incubations were at $37^{\circ} \mathrm{C}$.

Long-term starvation experiments. Bacteria were grown in MOPS medium for $24 \mathrm{~h}$, collected by centrifugation, resuspended in the same volume of $\mathrm{MOPS}_{0}$ buffer, diluted $1: 200$ into $50 \mathrm{ml}$ MOPS medium limited in $\mathrm{P}_{i}$ or in glucose $(0.04 \%, \mathrm{w} / \mathrm{v})$ in $500 \mathrm{ml}$ Erlenmeyer flasks (time zero), and further incubated with aeration in a shaking water bath. Every 4 or $5 \mathrm{~d}$, water was added to cultures to compensate for evaporation. At specified time intervals, $0.5 \mathrm{ml}$ samples were withdrawn, cells were collected by centrifugation, resuspended in $M 9_{0}$ buffer, and serial dilutions were spread in duplicate with $3 \mathrm{ml}$ soft agar on M9 agar medium containing appropriate concentrations of amino acids in order to measure titres of viable cells and revertants. C.f.u. were counted after $3 \mathrm{~d}$ (total cells) or $6 \mathrm{~d}$ (revertants) of incubation. Each graph represents data obtained from one experiment and is representative of several experiments. Variations between experiments in the concentrations of revertants were within one log at each time point.

Mixed-culture experiments. Of the two strains used, one (generally that used as the minor population) carried a Tn10 $\left(\mathrm{Tc}^{r}\right)$ antibiotic-resistance marker. Unless otherwise indicated (Fig. 3d), $\mathrm{Tc}^{\mathrm{r}}$ and $\mathrm{Tc}^{\mathrm{s}}$ bacteria were grown for $24 \mathrm{~h}$ in MOPS medium limited in glucose $(0.04 \%, \mathrm{w} / \mathrm{v})$, diluted $1: 200$ into MOPS medium limited in $\mathbf{P}_{\mathbf{i}}$ (time zero), grown for $24 \mathrm{~h}$, and mixed (day 1) by transferring $50 \mu \mathrm{l}$ of a 1:100 dilution in $\mathrm{MOPS}_{0}$ of the culture used as the minority into $50 \mathrm{ml}$ of a culture used as the majority (Zambrano et al., 1993). The mixed culture was further incubated with agitation; aliquots were removed at appropriate intervals and centrifuged, and bacteria were resuspended, serially diluted in $\mathrm{M}_{0}$, and plated in triplicate onto LB and LB-tetracycline agar media to determine the total number of viable cells and the number of $\mathrm{Tc}^{r}$ bacteria, respectively. In the case of nonsense suppressors, variations between experiments in the concentrations of revertants were less than one log at each time point, and data are averaged. In contrast, in the case of $\mathrm{Arg}^{+}, \mathrm{His}^{+}$and/or $\mathrm{Thr}^{+}$revertants, more variations were observed and data from several independent experiments are shown.

Growth in spent culture medium. Cultures were grown in $\mathrm{P}_{\mathrm{i}}$ limiting medium; $8 \mathrm{ml}$ aliquots were taken at appropriate intervals, and the cells were removed by centrifugation and filtration. The spent culture media were distributed into $16 \mathrm{~mm}$ glass test tubes ( $1 \mathrm{ml}$ aliquots), and supplemented with nutrients $(40-50 \mu \mathrm{l})$. ENZ361 bacteria grown overnight in MOPS medium limited in glucose $(0.05 \%, \mathrm{w} / \mathrm{v})$ were centrifuged, resuspended in the same volume of MOPS inoculate $(10 \mu \mathrm{l})$ the supplemented spent culture media. Cultures were incubated for $24 \mathrm{~h}$ with gentle agitation, and aliquots were serially diluted and plated in triplicate on LB agar medium to measure the number of viable cells. The experiment-to-experiment variation in the number of viable cells was less than $30 \%$ at each time point.

Determination of glucose and acetate concentrations. The determination of the concentrations of glucose and acetate in culture media was based on the enzymic formation of NADH measured by the increase in absorbance at $340 \mathrm{~nm}$. Glucose concentration was determined by the coupled enzyme reaction catalysed by hexokinase and glucose-6-phosphate dehydrogenase (glucose HK assay from Sigma); analysis of acetate used acetyl-CoA synthetase, citrate synthase and malate dehydrogenase (acetate assay from Boehringer). Assays were performed in duplicate according to the manufacturers' instructions. Variations between experiments were less than $10 \%$.

Assay of $\beta$-galactosidase. To measure the expression of the sulA:: lacZ fusion (Huisman \& D'Ari, 1983), $1 \mathrm{ml}$ samples were withdrawn and brought to a final concentration of $200 \mu \mathrm{g}$ chloramphenicol ml $\mathrm{ml}^{-1}$ to stop protein synthesis. $\beta$-Galactosidase measurements were carried out in duplicate as described previously (Dri \& Moreau, 1994). Activities are expressed per $O_{600}$ unit of cell suspensions measured with a Jasco V530 spectrophotometer in cells of $1 \mathrm{~cm}$ path length by using the following formula (after Miller, 1972): $\left[\left(\mathrm{OD}_{420}-1.75 \mathrm{OD}_{550}\right) \times\right.$ reaction volume $\left.\times 1000\right] /$ (reaction time $\times$ sample volume $\left.\times \mathrm{OD}_{600}\right) ; \mathrm{OD}_{420}$ and $\mathrm{OD}_{550}$ were read from the reaction mixture and time was in minutes.

UV irradiation. UV light of predominantly $254 \mathrm{~nm}$ was obtained from a $15 \mathrm{~W}$ germicidal lamp. The lamp output was about $1.5 \mathrm{~J} \mathrm{~m}^{-2} \mathrm{~s}^{-1}$. Samples in MOPS medium $(1.8 \mathrm{ml}$ in a $50 \mathrm{~mm}$ glass Petri dish) were irradiated for $5 \mathrm{~s}$ at $4{ }^{\circ} \mathrm{C}$, and $1.5 \mathrm{ml}$ portions in $16 \mathrm{~mm}$ glass test tubes were further incubated with agitation for $1 \mathrm{~h}$ at $37^{\circ} \mathrm{C}$.

\section{RESULTS}

\section{Degradation of exogenous arginine, threonine and glucose by $P_{i}$-starved cells}

The possibility that E. coli cells starved for $\mathrm{P}_{\mathrm{i}}$ under aerobic conditions may suffer from high cellular levels of ROS prompted us to determine whether this could increase the mutation rate in strain ENZ361, which carries notably the $t h r-1(\mathrm{Am})$, his $G 4(\mathrm{Oc})$ and $\operatorname{argE3}(\mathrm{Oc})$ mutations. At first sight, this seemed to be the case because, if the frequency of rifampicin-resistant mutants did not change significantly in cultures starved for $P_{i}$ or glucose (R. Duval \& P. L. Moreau, unpublished results), 


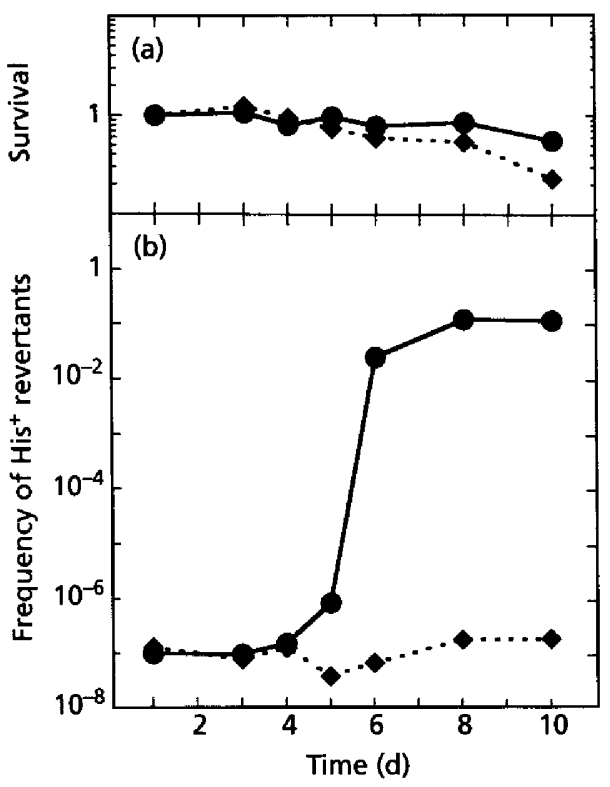

Fig. 1. Accumulation of prototrophic revertants during prolonged incubation in $P_{i}$-limiting medium. E. coli ENZ361 cells were grown to saturation in MOPS medium $\left(2.5 \times 10^{9}\right.$ cells $\mathrm{ml}^{-1}$ ), centrifuged, resuspended in the same volume of MOPS buffer, diluted 1:200 (designated time zero) into fresh medium limited in $P_{i}\left(P_{i}^{-}\right)(O)$ or in glucose $\left(G^{-}\right)(\diamond)$, and incubated further with aeration. Samples were withdrawn at the times indicated from day 1 through day 10 for measurements of the concentrations of viable cells (determined on M9 minimal agar medium) and $\mathrm{His}^{+}$revertants (selected on $\mathrm{M9}$ agar medium containing a limited amount of histidine; identical results were obtained when the medium contained no histidine). Survival (a) was determined as the viable cell concentration at each point divided by the viable cell concentration on day $1\left(6.2 \times 10^{8}\right.$ and $5.5 \times 10^{8} \mathrm{ml}^{-1}$ in $\mathrm{P}_{i}^{-}$and in $\mathrm{G}^{-}$medium, respectively). The frequency of $\mathrm{His}^{+}$revertants (b) was determined as the concentration of revertants divided by the concentration of viable cells at each point. Data are from one representative experiment. Similar time courses and yields of revertants were obtained whether the selection was for the $\mathrm{His}^{+}, \mathrm{Arg}^{+}$or $\mathrm{Thr}^{+}$ phenotype.

the frequency of prototrophic revertants did increase dramatically in cultures starved for $P_{i}$, but not in cultures starved for glucose (Fig. 1). By using Hfr-mating and P1transduction techniques, we determined that a typical $\mathrm{Thr}^{+} \mathrm{His}^{+} \mathrm{Arg}^{+}$revertant isolated from a 20-d-old culture in $\mathbf{P}_{\mathrm{i}}$-limiting medium (strain ENZ720) carried a suppressor mutation, tentatively designated as sup-720, that was co-transducible at $92 \%$ with the nadA57::Tn10 marker; sup-720 would be therefore equivalent to the known $\operatorname{supG}(\operatorname{supL})$ suppressor that is located close to nadA. The sup $G$ suppressor results from a single base substitution in lys'T that changes the anticodon of the lysine tRNA in such a way that both ochre and amber nonsense codons can be recognized (SuUUA/G) (Prather et al., 1983; Eggertsson \& Söll, 1988).

Mixed-culture experiments clearly indicate, however, that the suppressors produced in cultures starved for $P_{i}$

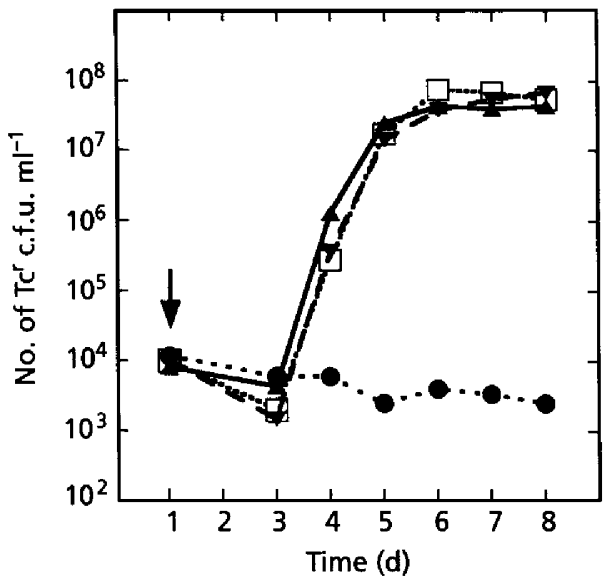

Fig. 2. Growth of supG suppressors in mixed culture. Strains ENZ725 (srl::Tn10) (O), ENZ849 (sup-720 srl::Tn10) (口), ENZ897

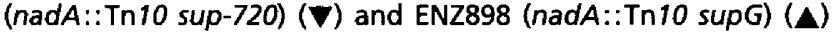
were grown for $1 \mathrm{~d}$ in $\mathrm{P}_{\mathrm{f}}$-limiting medium, and rediluted $1: 10^{5}$ into 1-d-old cultures of strain ENZ361 $\left(\mathrm{Tc}^{5}\right)$ in P-limiting medium. Cell mixtures were further incubated for the times indicated, and assayed for viable cells on LB-tetracycline. The total number of viable cells measured on LB medium decreased from about $6 \times 10^{8} \mathrm{ml}^{-1}$ on day 1 to about $4 \times 10^{8}$ cells $\mathrm{ml}^{-1}$ on day 8 of incubation. Data are the means of two independent experiments.

result from the growth of rare spontaneous mutants, rather than from an increase in the mutation rate in $\mathrm{P}_{\mathrm{i}^{-}}$ starved cells. When sup-720 suppressors carrying a $s r l:: \operatorname{Tn} 10\left(\mathrm{Tc}^{\mathrm{r}}\right)$ marker (strain ENZ849), grown for $1 \mathrm{~d}$ in $\mathrm{P}_{\mathrm{i}}$-limiting medium (or in glucose-limiting medium), were added as a minor population into a 1-d-old culture of ENZ361 cells grown in $\mathrm{P}_{\mathrm{i}}$-limiting medium, the former $\mathrm{Tc}^{\mathrm{r}}$ suppressors started to grow after 2 further days of incubation, and reached a maximal concentration of about $10^{8}$ cells $\mathrm{ml}^{-1}$ after 3 more days of incubation, while the total number of viable cells was

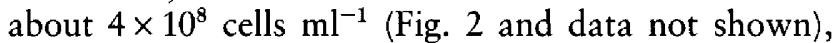
which mimics the normal production of revertants in a culture of ENZ361 cells starved for $\mathrm{P}_{i}$ (Fig. 1). In contrast, sup-720 suppressors grown in $\mathrm{P}_{\mathrm{i}}$-limiting or in glucose-limiting medium could not grow and eventually died when they were added as a minor population into a culture starved for glucose (data not shown).

Transduction into strain ENZ361 of the sup-720 mutation (yielding strain ENZ897) or of a true supG mutation (yielding strain ENZ898) gave rise to strains that grew in mixed cultures like sup- 720 mutants isolated from an old culture (strain ENZ849) (Fig. 2), which suggests that the presence of a single supG mutation is sufficient to permit cells to grow in a culture of ENZ361 bacteria starved for $P_{i}$. We can rule out the possibility that the presence of the $\operatorname{Tn} 10\left(\mathrm{Tc}^{\mathrm{r}}\right)$ antibioticresistance marker used to distinguish the populations in mixed-culture experiments could affect the cells' growth because identical results were obtained whether this marker was introduced into strains placed either as the 


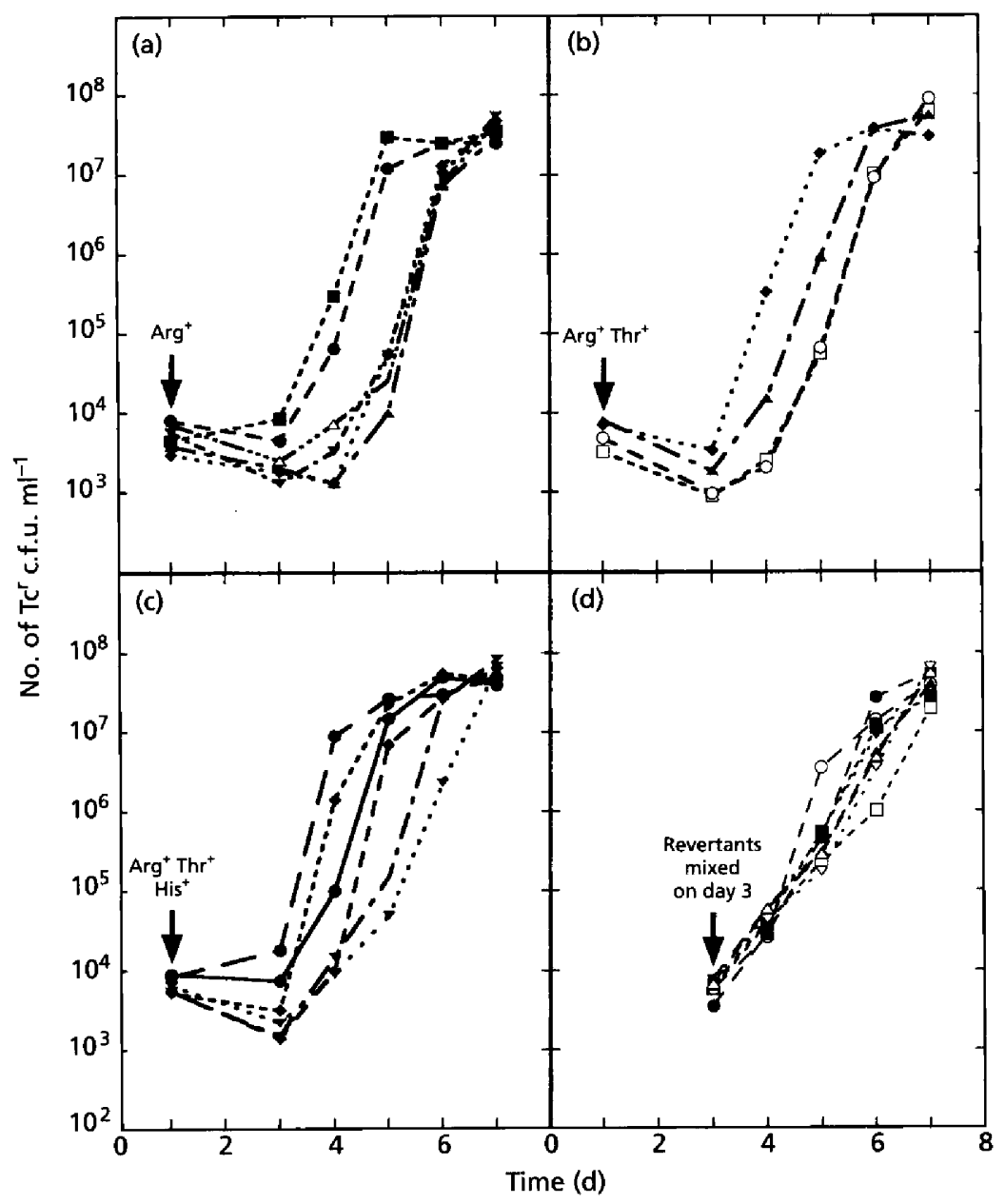

Fig. 3. Growth of $\mathrm{Arg}^{+}$revertants in mixed culture. In (a), (b) and (c), mixed-culture experiments were done with ENZ875 ( $\mathrm{Arg}^{+}$ srl::Tn10) (a), ENZ963 ( $\mathrm{Arg}^{+} \mathrm{Thr}^{+}$srl::Tn10) (b) and ENZ878 ( $\mathrm{His}^{+} \mathrm{Arg}^{+} \mathrm{Thr}^{+} \mathrm{srl}:: \mathrm{Tn} 10$ ) (c) revertants grown for $1 \mathrm{~d}$ in $\mathrm{P}_{\mathrm{i}}$-limiting medium and then rediluted $1: 10^{5}$ into $1-d-$ old cultures in $\mathrm{P}_{\mathrm{i}}$-limiting medium of strain ENZ361 $\left(\mathrm{Tc}^{5}\right)$ containing about $6.2 \times 10^{8}$ cells $\mathrm{ml}^{-1}$. In (d), 1-d-old $\mathrm{Arg}^{+} \mathrm{TC}^{\mathrm{r}}(\boldsymbol{\square}, \square), \mathrm{Arg}^{+}$ $\mathrm{Thr}^{+} \mathrm{Tc}^{\mathrm{r}}(\boldsymbol{\nabla}, \nabla)$ and $\mathrm{Arg}^{+} \mathrm{Thr}^{+} \mathrm{His}^{+} \mathrm{Tc}^{\mathrm{r}}(\mathbf{O}$, $O, \Delta, \Delta)$ revertants were rediluted $1: 10^{5}$ into 3 -d-old cultures in $P_{i}$-limiting medium of strain ENZ361 $\left(\mathrm{Tc}^{5}\right)$ containing about $4.1 \times 10^{8}$ cells $\mathrm{ml}^{-1}$. By day 7 , the total number of viable cells in cultures was about $3.6 \times 10^{8}$ cells $\mathrm{ml}^{-1}$. Data of several independent experiments are shown.

minor or as the major population in mixed cultures (data not shown), and introduction of the $s r l:: \operatorname{Tn} 10$ mutation into strain ENZ361 (yielding strain ENZ725) did not permit cells to grow in mixed culture (Fig. 2).

To determine whether reversion of the $t h r-1(\mathrm{Am})$, bis $G 4\langle\mathrm{Oc})$ and/or $\operatorname{argE3}(\mathrm{Oc})$ mutations in strain ENZ361 could account, at least in part, for the growth of sup $G$ suppressors in cultures starved for $\mathrm{P}_{\mathrm{i}}$, spontaneous revertants of strain ENZ361 $\left(\mathrm{Thr}^{+}, \mathrm{His}^{+}\right.$or $\mathrm{Arg}^{+}$) were isolated on M9 minimal medium (see Methods), and tested for their ability to grow in mixed culture. Fig. 3(a) shows that $\mathrm{Arg}^{+}$cells (strain ENZ875) could grow in mixed culture like supG suppressors, whereas $\mathrm{Thr}^{+}$or $\mathrm{His}^{+}$cells could not grow (data not shown). We checked that the $\mathrm{Arg}^{+}$cells had not accumulated secondary mutations suppressing the thr or bis mutations during growth in mixed culture (data not shown). Moreover, Fig. 3(a, b, c) shows that the strains selected successively as $\mathrm{Arg}^{+}$, $\mathrm{Thr}^{+}\left(\mathrm{Arg}^{+}\right)$, and $\mathrm{His}^{+}$ $\left(\mathrm{Arg}^{+} \mathrm{Thr}^{+}\right.$) all behaved similarly in mixed cultures, which supports the idea that $\sup G$ suppressors could grow in a culture of ENZ361 cells starved for $P_{i}$ primarily because of the reversion of the $\operatorname{argE} 3(\mathrm{Oc})$ mutation.
However, when $\mathrm{Arg}^{+}$bacteria [i.e. $\mathrm{Arg}^{+}$revertants (Fig. 3a, b, c), supG suppressors (ENZ898) (Fig. 2), or MG1655 wild-type bacteria (data not shown)] were added as a minor population into 1-d-old cultures of ENZ361 cells starved for $P_{i}$, the former bacteria started to grow only after a delay of several days. This delay could reflect either the period of time necessary for $\mathrm{Arg}^{+}$ bacteria to somehow adapt themselves to the growth conditions, or the period of time necessary for ENZ361 cells to condition the culture medium so as to permit $\mathrm{Arg}^{+}$bacteria to grow. The latter hypothesis appeared to be correct because $\mathrm{Arg}^{+}$revertants, as well as $\mathrm{Arg}^{+}$ $\mathrm{Thr}^{+}$and $\mathrm{Arg}^{+} \mathrm{Thr}^{+} \mathrm{His}^{+}$revertants, could start growing immediately without a delay when they were added into 3-d-old cultures (Fig. 3d).

To help define changes that occur in the composition of the $P_{i}$-limiting medium during incubation of ENZ361 cells, we determined which nutrients needed to be added into sterilized spent culture media taken at different time intervals to allow fresh ENZ361 cells, added at a low cell density, to grow to saturation (about $10^{9}$ cells $\mathrm{ml}^{-1}$ ) (Fig. 4a). As expected, by $7 \mathrm{~h}$ of incubation, when the growth rate of ENZ361 cells in $P_{i}$-limiting medium decreased abruptly (cells entered stationary phase), $P_{i}$ was the only 


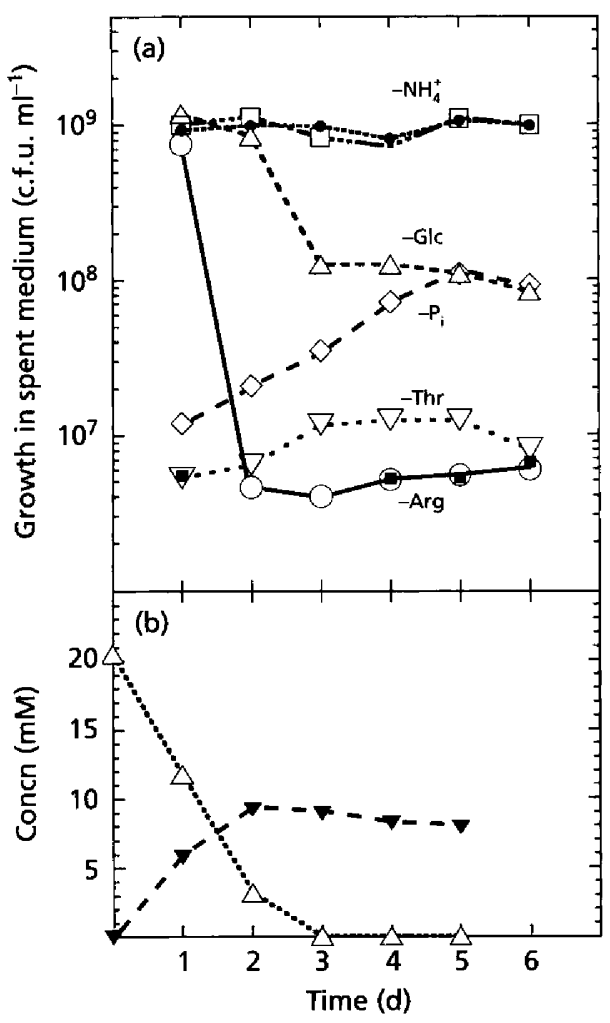

Fig. 4. Concentrations of nutrients in spent culture media. ENZ361 cells grown overnight in glucose-limiting medium were diluted $1: 200$ in $\mathrm{P}_{\mathrm{i}}$-limiting medium (time zero) and grown further with aeration. (a) At the times indicated, samples were withdrawn, sterilized by filtration and inoculated at a final concentration of about $6.5 \times 10^{6}$ cells $\mathrm{ml}^{-1}$ with ENZ361 cells starved for glucose. Media were either not supplemented ( $\boldsymbol{D}$ ), or supplemented with five nutrients $\left(10 \mathrm{mM} \mathrm{NH}_{4} \mathrm{Cl}, 5 \mathrm{mM}\right.$ $\mathrm{K}_{2} \mathrm{HPO}_{4}, 10 \mathrm{mM}$ glucose, $0.4 \mathrm{mM}$ threonine and $0.4 \mathrm{mM}$ arginine) (O), or with only four nutrients, one nutrient being omitted: $\mathrm{NH}_{4} \mathrm{Cl}(\square)$, glucose $(\triangle), \mathrm{P}_{\mathrm{i}}(\diamond)$, threonine $(\nabla)$ or arginine $(O)$. The reconstituted cultures were incubated for $24 \mathrm{~h}$, and the concentrations of viable cells were determined on LB agar medium. Data are the means of two independent experiments. (b) At the times indicated, the concentrations of glucose $(\triangle)$ and acetate $(\nabla)$ in spent culture media were determined by enzymic methods. Data are the means of four independent experiments.

limiting factor in the culture medium. However, by day 1 (24 h), day 2 and day 3 of incubation, threonine, arginine and glucose were in turn also in limiting amounts (data not shown). When a spent culture medium taken at a given time was supplemented with fresh ENZ361 cells and all the nutrients possibly in limiting amounts but one, bacterial growth would be therefore proportional to the actual concentration in the spent culture medium of the nutrient that was omitted. The results of such an assay performed at various time intervals, and by omitting various nutrients (Fig. 4a) indicate that the same nutrients that were depleted from the culture medium (or metabolites) could be subsequently excreted to, and somewhat accumulated in, the culture medium depending on the rate at which they were reutilized. Notably, the concentration of $P_{i}$ in the culture medium appeared to increase steadily during the first $5 \mathrm{~d}$ of incubation (Fig. $4 \mathrm{a}$; curve $-\mathrm{P}_{\mathrm{i}}$ ), which indicates that $P_{i}$ was actually excreted by non-growing bacteria. It is known that cells entering stationary phase under $\mathrm{P}_{\mathrm{i}}$-starvation conditions maintain high intracellular $\mathrm{P}_{\mathrm{i}}$ levels (about $7 \mathrm{mM}$ ) (Rao et al., 1993; N. W. Lutz \& P. L. Moreau, unpublished results), which provides a potential source of $\mathrm{P}_{i}$. Like $\mathrm{P}_{i}$, threonine was totally depleted from the culture medium after $1 \mathrm{~d}$ of incubation, and was subsequently excreted (Fig. 4a; curve - Thr), which suggests that this amino acid was degraded only partially by $P_{i}$-starved cells. At first glance, it seemed that bacteria starved for $P_{i}$ also metabolized glucose only partially (Fig. 4a; curve - Glc). In fact, enzymic methods of analysis (Fig. 4b) showed that the concentration of glucose decreased from about $20 \mathrm{mM}$ in fresh medium to undetectable levels (less than $0.05 \mathrm{mM}$ ) in a 3-d-old culture medium, while the concentration of acetate increased up to about $10 \mathrm{mM}$ by day 2 of incubation, which indicates that $P_{i^{-}}$ starved cells can totally degrade glucose to products such as acetate. Likewise, arginine appeared to be used slowly but extensively by $\mathrm{P}_{\mathrm{i}}$-starved cells, as indicated by the fact that by day 2 of incubation, spent culture media supplemented with all the required nutrients except arginine could not support any bacterial growth (Fig. 4a; curve -Arg). Arginine degradation can occur through three different pathways: the arginine succinyltransferase pathway (astBC-dependent) induced by nitrogen and carbon limitation, to produce ammonia; the biodegradative arginine decarboxylase pathway (adiAdependent) induced by anaerobic and acidic growth conditions; and the constitutive biosynthetic arginine decarboxylase pathway (speAB-dependent), used to produce putrescine (Glansdorff, 1996; Reitzer, 1996; Stim-Herndon et al., 1996; Schneider et al., 1998). We can rule out the possibility that arginine was used as a source of nitrogen because ammonium, the preferred nitrogen source, was not in limiting amount in spent culture media (Fig. 4a; curve $-\mathrm{NH}_{4}^{+}$), and inactivation of $a s t B$ or ast $C$ had no effect on the rate of degradation of arginine during $\mathrm{P}_{\mathrm{i}}$-starvation (data not shown). Likewise, inactivation of adiA had no effect on arginine degradation (data not shown). In fact, the degradation of arginine appeared to occur through the biosynthetic arginine decarboxylase (SpeA)-initiated pathway to produce agmatine and putrescine because putrescine, which is a weak inhibitor of SpeA activity (Glansdorff, 1996), preferentially delayed the degradation of arginine when it was added into $\mathrm{P}_{\mathrm{i}}$-limiting medium to a final concentration of $10 \mathrm{mM}$ (data not shown).

Taken together, these results show that ENZ361 cells starved for $\mathrm{P}_{\mathrm{i}}$ can maintain an active metabolism for at least $3 \mathrm{~d}$, which modifies the composition of the culture medium and, ultimately, the composition of the bacterial population because, when arginine is totally depleted from the culture medium, only spontaneous $\mathrm{Arg}^{+}$revertants present in the culture can grow by using the nutrients, notably $P_{i}$, acetate and threonine, that are progressively excreted by the bulk of the population. 


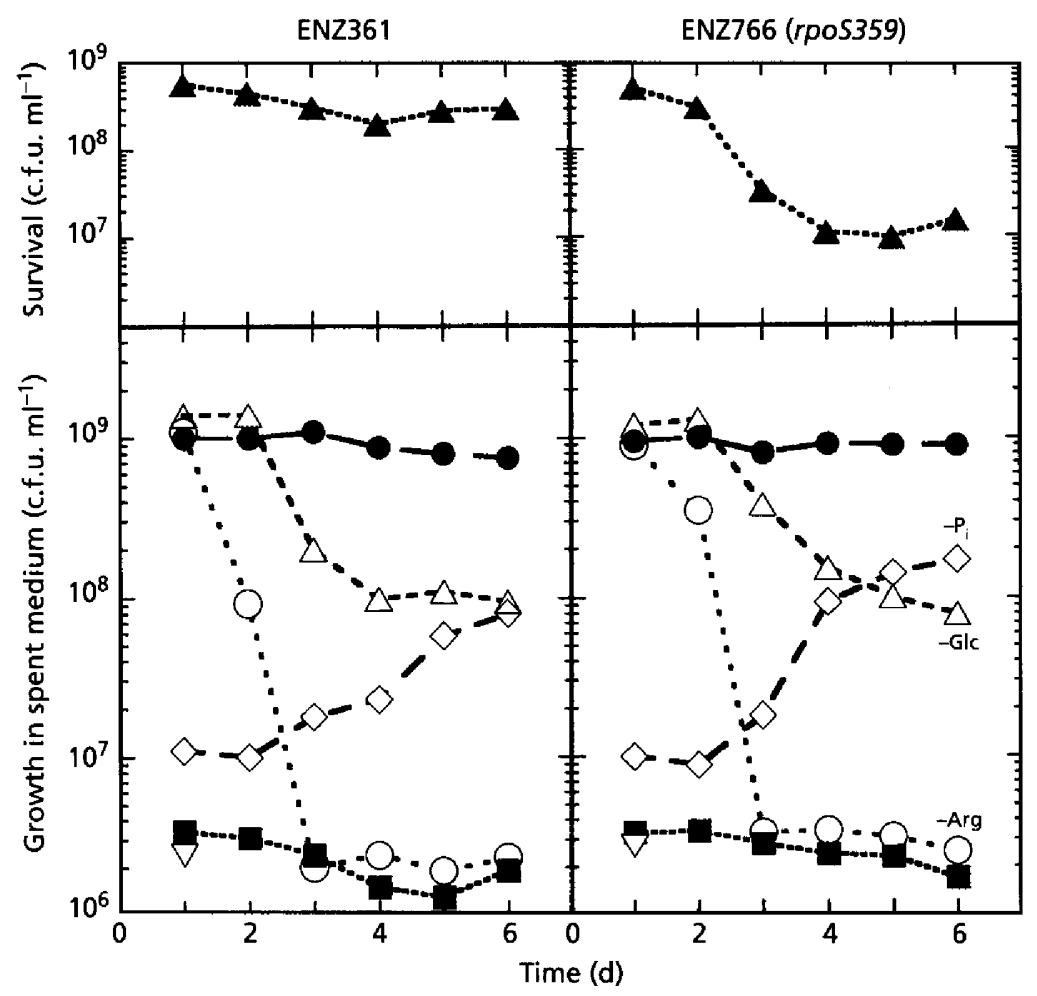

\begin{abstract}
Fig. 5. Role of RpoS. Experiments were done as described in the legend to Fig. 4 except that each culture in $P_{i}$-limiting medium was inoculated directly with a single colony grown on LB medium (bacteria were not pre-grown in MOPS medium limited in glucose to avoid the production of secondary mutations in rpos mutants). Survival (measured on LB medium) of strains ENZ361 and ENZ766 (rpoS359::Tn10) during prolonged incubation in $\mathrm{P}_{\mathrm{i}}$-limiting medium is shown in the top panels. At the times indicated, samples were withdrawn, sterilized by filtration and inoculated with ENZ361 cells starved for glucose at a final concentration of about $3 \times 10^{6}$ cells $\mathrm{ml}^{-1}$. Media were either not supplemented $(\mathbf{D})$. or supplemented with four nutrients $(5 \mathrm{mM}$ $\mathrm{K}_{2} \mathrm{HPO}_{4}, 10 \mathrm{mM}$ glucose, $0.4 \mathrm{mM}$ threonine and $0.4 \mathrm{mM}$ arginine) (0), or with only three nutrients, one nutrient being omitted: glucose $(\Delta), P_{i}(\diamond)$, threonine $(\nabla)$ or arginine $(O)$. The reconstituted cultures were incubated for $24 \mathrm{~h}$ and the concentrations of viable cells were determined on LB medium (lower panels). The data are from a representative experiment from three separate trials. By day 6 , the concentrations of acetate in cultures of strains ENZ361 and ENZ766 (rpoS359:: Tn10) were, respectively, 7.3 and $7.2 \mathrm{mM}$.
\end{abstract}

\section{Protective role of the RpoS regulon during $P_{i}$ starvation}

Because supG suppressors rather than $\mathrm{Arg}^{+}$revertants were found in old cultures starved for $\mathrm{P}_{\mathrm{i}}$ (Fig. 1 and data not shown), it is probable that reversion of other nonsense mutation $(\mathrm{s})$ than the $\operatorname{argE3}(\mathrm{Oc})$ mutation may provide a growth advantage to sup $G$ suppressors. Mere reversion of the $t h r-1(\mathrm{Am})$ mutation, or of the $h i s G 4(\mathrm{Oc})$ mutation, or of both cannot account for this result because $\mathrm{Arg}^{+} \mathrm{Thr}^{+}$and $\mathrm{Arg}^{+} \mathrm{Thr}^{+} \mathrm{His}^{+}$revertants did not exhibit a significant growth advantage over $\mathrm{Arg}^{+}$ revertants in mixed cultures (Fig. 3). Two lines of evidence then pointed to the $r p o S$ gene. First, it has been shown recently that $E$. coli strains derived from AB1157, such as ENZ361, carry an amber mutation in rpoS that can be only partially suppressed by the weak amber suppressor supE44 also carried by these strains (Visick \& Clarke, 1997); this seemed to be true as judged from the different catalase activities exhibited by strain ENZ361 and $r p o S$ derivatives (see Methods). Second, $P_{i}$ starvation strongly induces the expression of the $r p o S$ gene (Lange \& Hengge-Aronis, 1991), and $\mathrm{P}_{\mathrm{i}}$-starved cells contain high cellular levels of RpoS (Gentry et al., 1993; Hengge-Aronis, 1996), which suggests that an increase in RpoS activity may somehow protect cells starved for $P_{i}$.

To assess the possible role of RpoS during $P_{1}$ starvation, we constructed and studied the behaviour of an rpoS null mutant. Fig. 5 shows that introduction of the rpoS359 allele in strain ENZ361 (giving rise to strain
ENZ766) provoked a dramatic decrease in cell viability between day 2 and day 4 of incubation under $\mathrm{P}_{\mathrm{i}^{-}}$ starvation conditions (top panels), whereas the rates of degradation of arginine and glucose were only slightly affected (lower panels). Therefore, a simple interpretation of the observation that $\sup G$ suppressors rather than $\mathrm{Arg}^{+}$revertants were found in $\mathrm{P}_{\mathrm{i}}$-starved cultures is that a $\sup G$ mutation would suppress the rpoS(Am) mutation more strongly than does the original supE44 mutation carried by strain ENZ361, thereby increasing RpoS activity, cell viability under $\mathrm{P}_{\mathrm{i}}$-starvation conditions, and hence ability to grow in old cultures. This idea was further supported by the finding that strain MG1655 $\left(r p o S^{+}\right)$exhibits a viability slightly higher than strain ENZ361 [rpoS(Am) supE44] under $\mathrm{P}_{\mathrm{i}}$-starvation conditions (see Fig. 7a, b).

\section{Recombinational repair of DSB in $\mathrm{P}_{\mathrm{i}}$-starved cells}

The possibility that a better protection of $\mathrm{Arg}^{+}$ revertants, through the expression of RpoS-controlled genes, could increase their ability to grow in a culture starved for $P_{i}$ prompted us to test the role of LexAcontrolled DNA repair genes (Walker, 1996), which are also induced under $\mathrm{P}_{\mathrm{i}}$-starvation conditions (Dri \& Moreau, 1993). Mutations that prevent induction of the LexA regulon (lexA-Ind ${ }^{-}$; Fig. 6a) or that inhibit recombinational repair, i.e. recA (Fig. 6b) and ruvA (Fig. $6 \mathrm{c})$, delayed the production of revertants in a culture starved for $P_{i}$, whereas inactivation of other DNA repair genes, such as uvrA, whose product catalyses excision of 


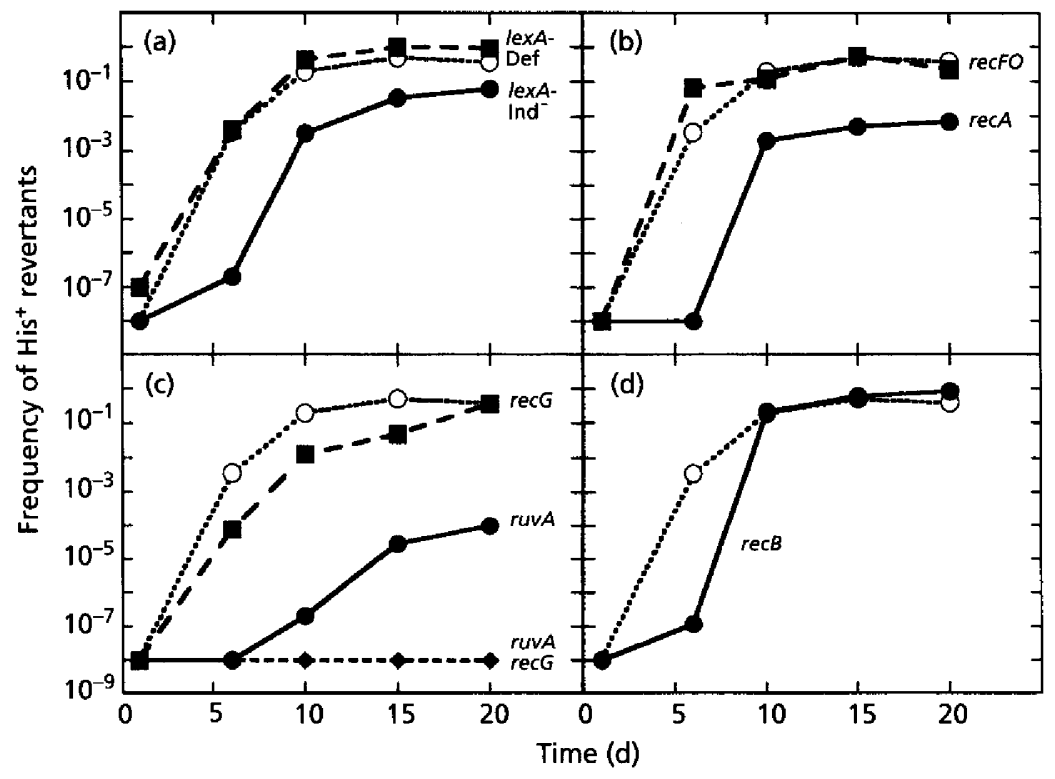

Fig. 6. Altered ability of recombination mutants to accumulate prototrophic revertants during prolonged incubation in P.-limiting medium. Experiments were done as described in the legend to Fig. 1. For each strain, the total number of viable cells measured on day 1 of incubation is indicated in parentheses. (a) ENZ616 (lexADef) $\left(4.7 \times 10^{8}\right.$ cells $\left.\mathrm{ml}^{-1}\right)(0)$ and ENZ701 (lexA-Ind $)^{-} \quad\left(5.6 \times 10^{8}\right.$ cells $\left.\mathrm{ml}^{-1}\right)(0)$; (b) ENZ618 (recA) $\left(3.6 \times 10^{8}\right.$ cells $\left.\mathrm{ml}^{-1}\right)(0)$ and ENZ644 (recFO) $\left(4.1 \times 10^{8}\right.$ cells $\left.\mathrm{ml}^{-1}\right)(\square) ;(\mathrm{c})$ ENZ625 (recG) $\left(4.7 \times 10^{8}\right.$ cells $\left.\mathrm{ml}^{-1}\right)$ (D), ENZ702 (ruvA) $\left(2.5 \times 10^{8}\right.$ cells $\left.\mathrm{ml}^{-1}\right)$ (0) and ENZ833 (ruvA recG) $\left(8.5 \times 10^{7}\right.$ cells $\left.\mathrm{ml}^{-1}\right)(\diamond)$; and (d) ENZ678 (recB) (O) $\left(2.2 \times 10^{8}\right.$ cells $\left.\mathrm{ml}^{-1}\right)$. Values obtained with parental strain ENZ361 $\left(6.6 \times 10^{8}\right.$ cells $\left.\mathrm{ml}^{-1}\right)(\mathrm{O})$ are reported for comparison. For each strain, the data are from a representative experiment from several separate trials.

Table 2. The recB mutation prevents the induction of the sulA::lac $Z$ fusion in $P_{\mathrm{i}}$-starved cells

Each strain was grown overnight in glucose-limiting medium, diluted $1: 200$ into $50 \mathrm{ml} \mathrm{P}_{\mathrm{i}}$-limiting medium (time zero) in a $500 \mathrm{ml}$ Erlenmeyer flask, and grown further with aeration. At an $\mathrm{OD}_{600}$ of about 0.25 (exponential growth phase), a sample was withdrawn from each culture and split into three parts: one part was left untreated; one part was UV-irradiated (approx. $7.5 \mathrm{~J} \mathrm{~m}^{-2}$ ), brought to $2 \mathrm{mM} \mathrm{K}_{2} \mathrm{HPO}_{4}$ and further incubated for $1 \mathrm{~h}$; and one part was supplemented with $25 \mu \mathrm{g}$ nalidixic acid (Nal) $\mathrm{ml}^{-1}$ and $2 \mathrm{mM} \mathrm{K}_{2} \mathrm{HPO}_{4}$ and further incubated for $2 \mathrm{~h}$. The specific activity of $\beta$ galactosidase was then determined in each portion. The cultures in $\mathrm{P}_{\mathrm{i}}$-limiting medium were further incubated for $28 \mathrm{~h}$ and assayed for $\beta$-galactosidase activity as described in Methods. The $\mathrm{OD}_{600}$ values of the cultures after $28 \mathrm{~h}$ incubation were about $0.72,0.77$ and 0.58 for strains ENZ376, ENZ409 and ENZ679, respectively. The values are the means ( \pm SD) of three (strain ENZ376) or four (strains ENZ409 and ENZ679) independent experiments.

\begin{tabular}{|c|c|c|c|c|}
\hline \multirow[t]{3}{*}{ Strain } & \multicolumn{4}{|c|}{$\beta$-Galactosidase activity } \\
\hline & \multicolumn{3}{|c|}{ Exponential growth } & \multirow{2}{*}{$\begin{array}{c}\mathrm{P}_{\mathrm{i}} \text { starvation } \\
28 \mathrm{~h}\end{array}$} \\
\hline & Untreated & $+\mathrm{UV}$ & $+\mathrm{Nal}$ & \\
\hline ENZ376 & $137 \pm 19$ & $2840 \pm 457$ & $3360 \pm 385$ & $1328 \pm 31$ \\
\hline ENZ409 (bns-205) & $212 \pm 32$ & $2207 \pm 345$ & $2322 \pm 386$ & $501 \pm 100$ \\
\hline ENZ679 (recB) & $30 \pm 5$ & $842 \pm 278$ & $36 \pm 2$ & $49 \pm 2$ \\
\hline
\end{tabular}

bulky lesions, had no effect (data not shown), which suggests that recombinational repair may protect $\mathrm{P}_{\mathrm{i}}$ starved cells. The investigation was thus extended to other recombination genes that are not under the control of LexA. Although introduction of a rec $G$ mutation, which disables a helicase required with $\mathrm{RuvABC}$ to process RecA-mediated recombination intermediates (i.e. Holliday junctions) (Lloyd \& Low, 1996), had only a slight inhibiting effect on the rate of production of revertants (Fig. 6c), inactivation of both ruvA and recG genes prevented any accumulation of revertants (Fig. $6 \mathrm{c}$ ), which confirms the involvement of recombination mechanisms under $\mathrm{P}_{\mathrm{i}}$-starvation conditions. Alterations in the $\mathrm{recF}$, recO and $\mathrm{recR}$ genes (Fig. $6 \mathrm{~b}$ and data not shown), whose products are collectively required to initiate recombinational repair of single-strand gaps generated from bulky lesions (Umezu \& Kolodner, 1994; Cox, 1997) had, however, no effects on the production of revertants, which excludes the possibility that such DNA damage may occur in significant amount in $\mathrm{P}_{\mathrm{i}}$-starved cells. In contrast, the production of revertants was significantly affected by introduction of a $r e c B$ mutation (Fig. $6 \mathrm{~d}$ ) that affects RecBCD, an enzyme required to initiate recombinational repair of DSB 


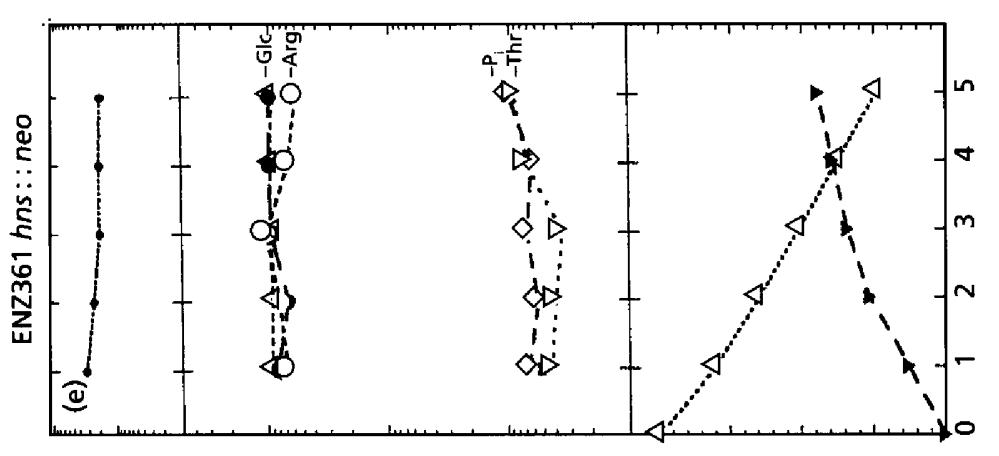

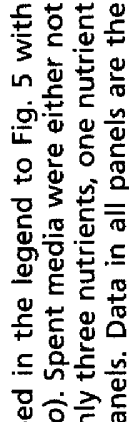

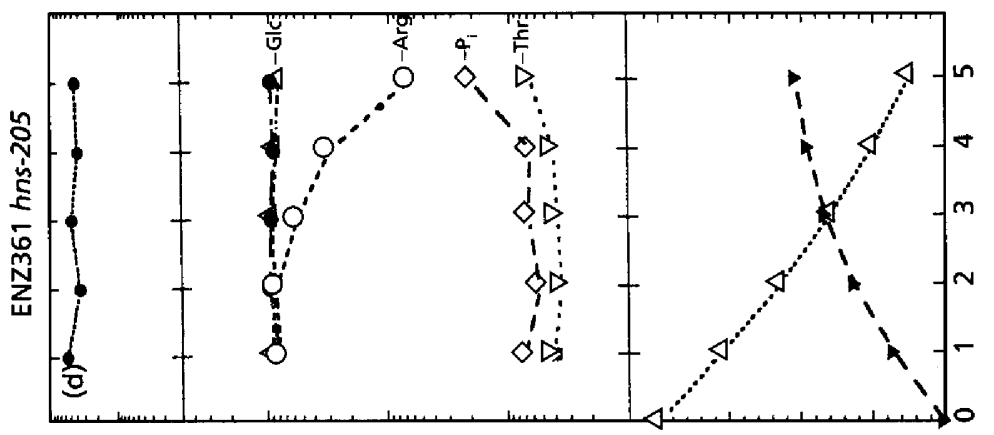

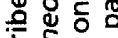

岁苍萃

ه

唡

요은

\%。

3氞言

空京的

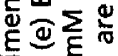

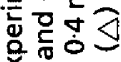

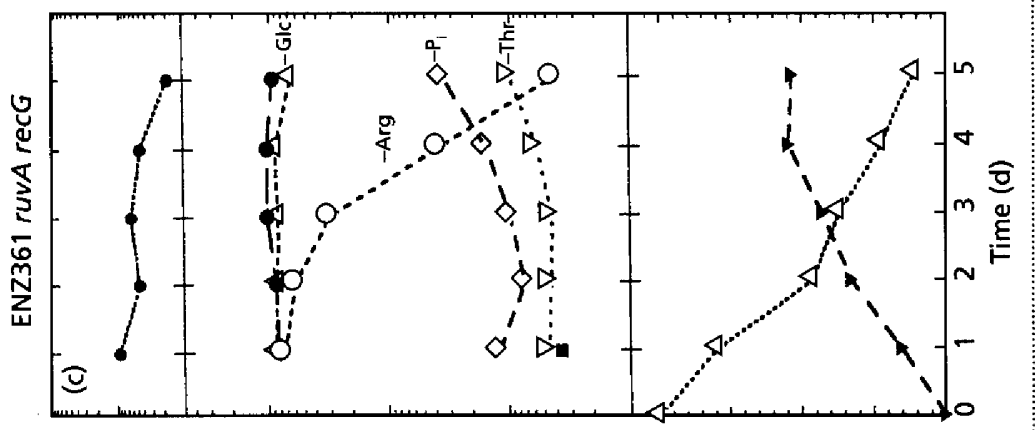

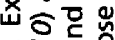

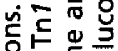

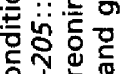

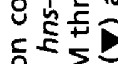

$\div \bar{\varepsilon}$

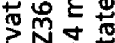

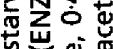

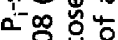

혼흥

5

$\varepsilon \widehat{\mathrm{\theta}} \mathrm{\varepsilon}$

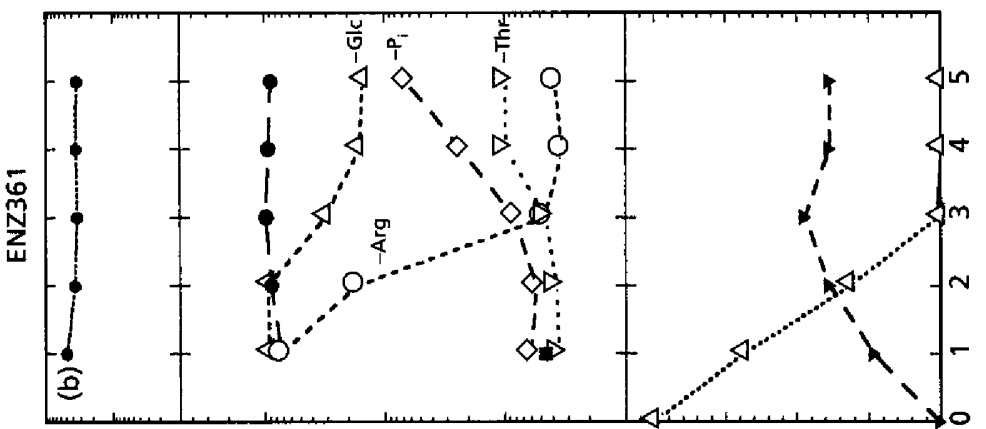

뜽 정으

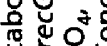

눈

Eิ등

它保

№n

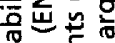

$>m .0$

올늘

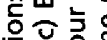

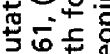

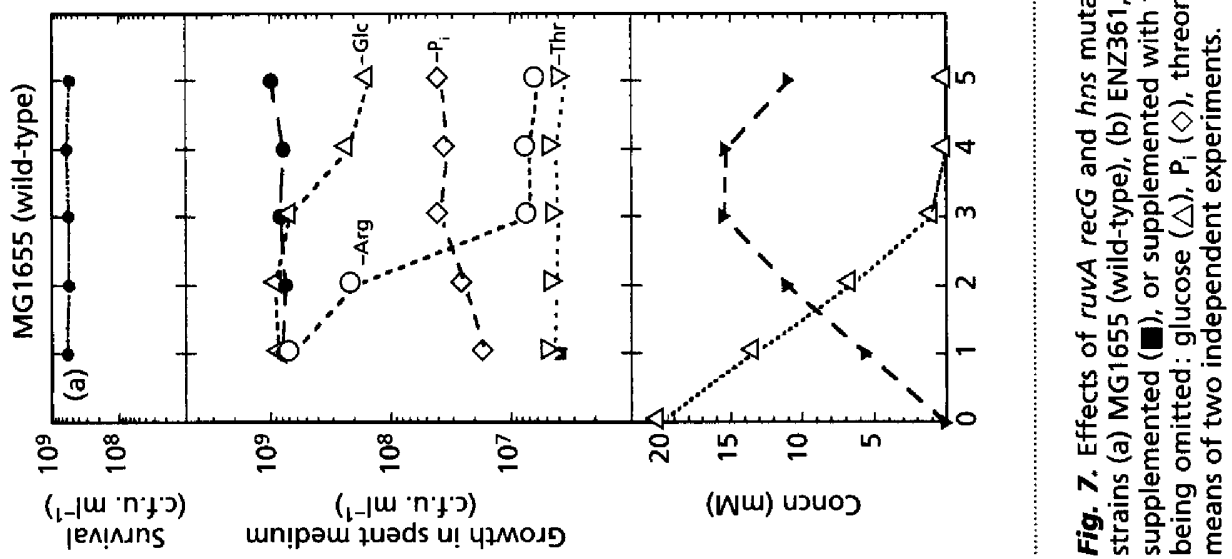


(Lloyd \& Low, 1996; Cox, 1997). RecBCD binds exclusively to double-stranded DNA with nearly flush ends, and generates through its helicase and nuclease activities single-stranded DNA (ssDNA) used eventually by $\operatorname{RecA}$ to promote recombination and repair (Kowalczykowski et al., 1994). Taken together, these data imply (i) that DSB are produced during the first days of incubation following starvation for $P_{i}$, (ii) that these potentially lethal lesions are repaired by the combined activities of the RecBCD, RecA, RecG and RuvABC recombination proteins, and (iii) that the efficiency of repair is enhanced through the induction of the LexA regulon which includes $r e c A$ and $r u v A B$.

\section{Induction of the LexA regulon is triggered by DSB produced under aerobic growth conditions}

Induction of LexA-controlled genes is triggered by the same ssDNA that is eventually implicated in RecAmediated recombination; this is because the RecA filament formed with ssDNA first stimulates the cleavage of the LexA repressor before promoting strand exchange (Moreau, 1987). In the case of DSB generated by radicals or nalidixic acid (an inhibitor of DNA gyrase), cleavage of the LexA repressor and induction of LexA-controlled genes such as recA or sulA thus require the activity of the RecBCD enzyme to generate ssDNA and facilitate the loading of RecA (Moreau, 1988; Sassanfar \& Roberts, 1990; Anderson \& Kowalczykowski, 1998). As shown in Table 2, induction of the LexA regulon, measured by using a sulA::lacZ fusion, was dramatically reduced following starvation for $P_{i}$ as well as treatment with nalidixic acid in strain ENZ679, which carries a recB mutation; this indicates that DSB are the main DNA damage that triggers induction of the LexA regulon in $P_{i}$-starved cells.

The level of expression of the sulA::lacZ fusion was also dramatically reduced in exponentially growing $\mathrm{rec} B$ mutants (strain ENZ679) compared to rec $B^{+}$cells (strain ENZ376) (Table 2), which is in good agreement with the notion that DSB are normally produced in growing cells (Lloyd \& Low, 1996) due to the production of $\mathrm{H}_{2} \mathrm{O}_{2}$ by aerobic metabolism (González-Flecha \& Demple, 1997). Likewise, the level of expression of the sulA::lacZ fusion in strain ENZ376 appeared to be strictly dependent upon the level of aeration of the cultures starved for $\mathrm{P}_{\mathrm{i}}$ : the higher the level of aeration, the higher the level of expression of the sulA promoter (P. L. Moreau, unpublished results), which suggests that DSB produced in $\mathrm{P}_{\mathrm{i}}$-starved cells also result from aerobic metabolism.

\section{H-NS helps maintain a rapid degradation of arginine and glucose}

Because $\mathrm{H}-\mathrm{NS}$ is required for a full induction of the LexA regulon in $P_{i}$-starved cells (Dri \& Moreau, 1993; Table 2), the potential role of $\mathrm{H}$-NS during $\mathrm{P}_{\mathrm{i}}$ starvation was further examined. Surprisingly, it appeared that cultures of hns mutant bacteria starved for $P_{i}$ could neither accumulate prototrophic revertants upon prolonged incubation, nor permit $h n s^{+} \sup G$ revertants to grow in mixed cultures (data not shown). These results can be simply explained, however, by the finding that hns mutant bacteria starved for $\mathrm{P}_{\mathrm{i}}$ exhibited much reduced rates of arginine degradation compared to $h n s^{+}$ cells (Fig. $7 \mathrm{~d}$, e): an excess of arginine in the growth medium is indeed expected to prevent $\mathrm{Arg}^{+}$revertants from expressing any growth advantage over $\arg E$ parent bacteria. The inhibiting effect of $b n s$ mutations was not limited to arginine degradation since the rate of glucose degradation was also reduced about twofold under $P_{i}$ starvation conditions in bns mutants compared to $\mathrm{hns}^{+}$ cells (Fig. 7d, e). As expected, the inhibition of arginine and glucose degradation was even stronger in bns::neo mutants (Fig. 7e), which produce practically no $\mathrm{H}-\mathrm{NS}$ protein, than in $h n s-205::$ Tn10 mutants (Fig. 7 d), which produce a truncated $\mathrm{H}-\mathrm{NS}$ protein with some residual activity (Dersch et al., 1994). Although these results are reminiscent of those observed with $\operatorname{ruvA} \operatorname{rec} G$ mutant bacteria (Fig. 6c, Fig. 7c), the viability of bns mutants, in contrast to that of ruvA recG mutants, was not specifically affected during prolonged incubation under $\mathrm{P}_{\mathrm{i}}$-starvation conditions (Fig. $7 \mathrm{c}, \mathrm{d}, \mathrm{e}$ ), which suggests that a primary role of $\mathrm{H}$-NS in $\mathrm{P}_{\mathrm{i}}$-starved cells is to sustain metabolic activities rather than DNA repair mechanisms (and indirectly cell metabolism). This notion may, however, help explain the inhibiting effect of $h n s$ mutations on the expression of the LexA regulon under $\mathrm{P}_{\mathrm{i}}$ starvation conditions because a lower rate of metabolism in $\mathrm{P}_{\mathrm{i}}$-starved $h n s$ mutants may decrease the rate of production of ROS, the amount of DSB, and thus the level of induction of LexA-controlled DNA-repair genes.

\section{DISCUSSION}

We show here that E. coli strains ENZ361 and MG1655 (wild-type) incubated under aerobic, $\mathrm{P}_{\mathrm{i}}$-starvation conditions still exhibit a high viability, although they totally degrade exogenous glucose to products such as acetate. Does this mean that $\mathrm{P}_{\mathrm{i}}$-starved cells, like apparently glucose-starved cells (Nyström et al., 1996), use anaerobic (Pfl) or semi-anaerobic (PoxB) enzymes to metabolize glucose to acetate, which decreases the activity of the aerobic respiratory chain and, thus, the generation of potentially lethal ROS? This is probably not the case, for the following reasons. First, the fermentative enzyme pyruvate formate-lyase $(\mathrm{Pfl})$, which is thought to be used by glucose-starved cells to produce acetate (Nyström, 1994; Nyström et al., 1996), is synthesized in dramatically reduced amounts in $\mathrm{P}_{\mathrm{i}^{-}}$ starved cells (VanBogelen et al., 1996). Second, pyruvate oxidase (PoxB), which may be preferentially used to produce acetate when bacteria approach the stationary phase, is unlikely to play a key role under $P_{i}$-starvation conditions because the expression of poxB is strictly controlled by RpoS (Chang et al., 1994), and the metabolism of glucose to acetate was essentially independent of RpoS in $\mathrm{P}_{\mathrm{i}}$-starved cells. Therefore, cells starved for $P_{i}$ should mainly use the PDH (NADdependent)/Pta/AckA shunt to metabolize pyruvate to acetate (Fig. 8), just as cells growing under aerobic, 

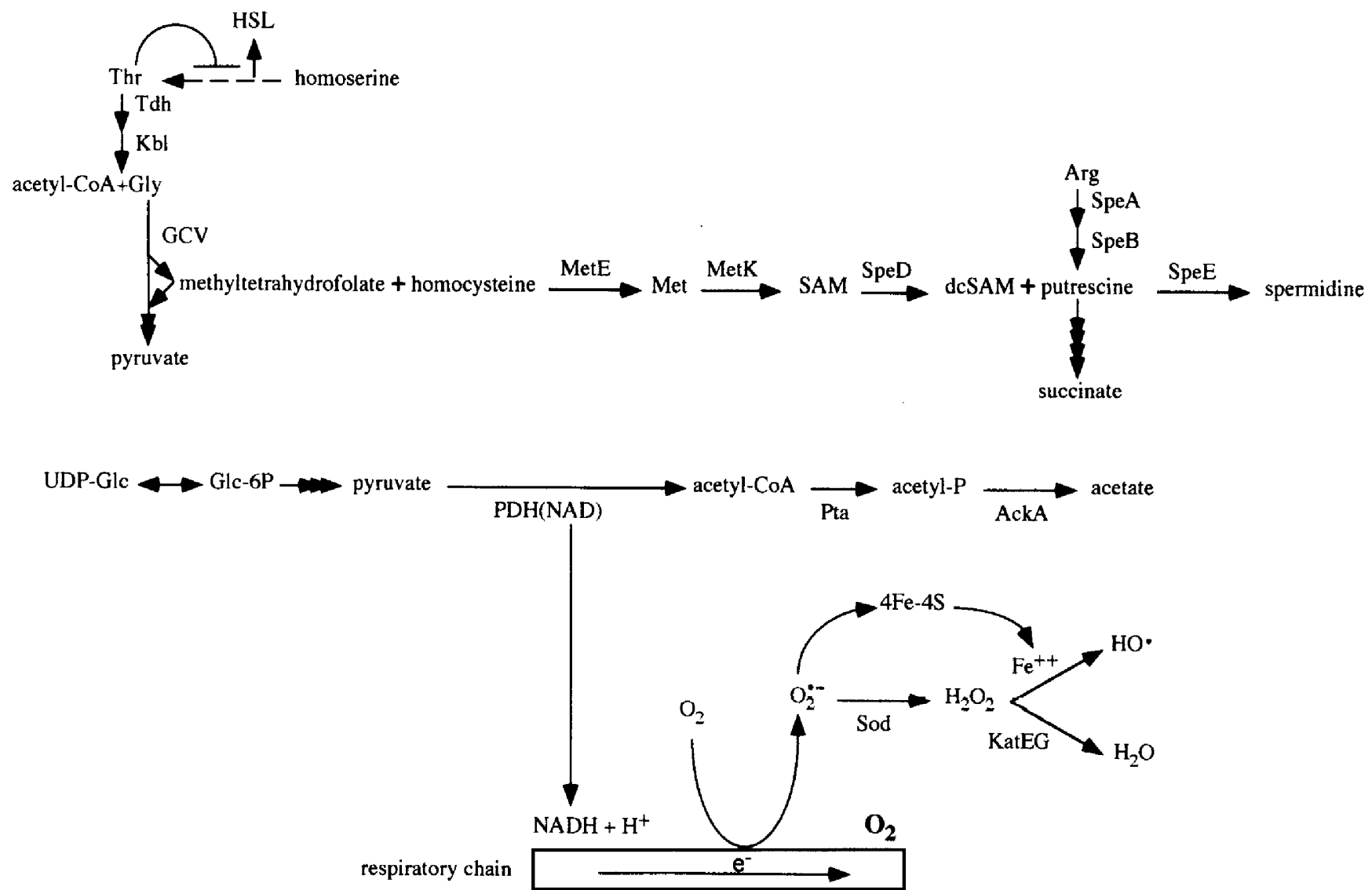

Fig. 8. Diagram showing the proposed pathways for the degradation of threonine, arginine and glucose, and for the production of ROS, in $\mathrm{P}_{\mathrm{i}}$-starved cells. H-NS may inhibit the synthesis of Tdh and Kbl, and thus may enhance the synthesis of homoserine lactone (HSL); on the other hand, H-NS may enhance the synthesis of PDH (AceEF-Lpd), thereby increasing the metabolism of glucose to acetate. Because UDP-Glc inhibits RpoS activity, whereas HSL and acetate enhance RpoS activity, H-NS may globally increase RpoS activity which in turn increases the activity of the catalases KatE and KatG. GCV, glycine cleavage system (GcvHPT-Lpd); dcSAM, decarboxylated S-adenosylmethionine. See Discussion for details.

excess-glucose conditions do (El-Mansi \& Holms, 1989; Holms, 1996).

If the above conclusion is correct, $\mathrm{P}_{\mathrm{i}}$-starved cells might be exposed to high levels of ROS generated by enzymes of the respiratory chain while glucose is metabolized. Several lines of evidence show that this is the case. As indicated by the growth kinetics of nonsense suppressors in cultures starved for $P_{i}$, survival and metabolism of starved cells was dependent upon RecBCD, RecA, RecG and RuvABC, which are required to repair DSB (Lloyd \& Low, 1996), a damage produced mainly through hydroxyl radical attack on DNA sugar (Keyer \& Imlay, 1996; Henle \& Linn, 1997). As expected, since repair of DSB through recombinational processes is essentially error-free (Lloyd \& Low, 1996), the mutation rate was not significantly increased in $\mathrm{P}_{\mathrm{i}}$-starved cells. The notion that $\mathrm{P}_{\mathrm{i}}$-starved cells are exposed to ROS attack, and that repair of DNA damage (i.e. DSB) requires recombination proteins helps explain (i) the requirement in these cells of the induction of the LexA regulon (lex $A^{+}$ genotype), and (ii) the fact that the LexA regulon is actually induced in $P_{i}$-starved cells (Dri \& Moreau,
1993) as in cells exposed to increased superoxide production (Brawn \& Fridovich, 1985), which may enhance the DNA-repair efficiency by increasing the cellular levels of RecA and RuvAB proteins. That the efficiency of induction of the LexA regulon in $\mathrm{P}_{\mathrm{i}}$-starved cells depends upon the level of aeration of the cultures supports the idea that DNA is then damaged because of aerobic metabolism. Finally, the finding that induction of the LexA regulon in $\mathbf{P}_{i}$-starved cells is totally prevented by introduction of a recB mutation clearly indicates that DSB are the main DNA damage produced during starvation for $P_{i}$.

The requirement of RpoS-dependent functions for survival of $P_{i}$-starved cells while glucose was metabolized may thus be explained by the key role played by RpoS-controlled gene products (i.e. KatG, KatE and Dps) in the defence of DNA against ROS (Hengge-Aronis, 1996). This idea is supported by the finding that the level of induction of the LexA regulon in $\mathrm{P}_{\mathrm{i}}$-starved cells is inversely related to RpoS activity, which suggests that the higher the RpoS activity, the lower the number of DSB, and thus the lower the level of 
induction of the LexA regulon (P. L. Moreau, unpublished results). Likewise, the degradation of threonine and arginine observed under $\mathrm{P}_{\mathrm{i}}$-starvation conditions may be explained by the synthesis of putrescine and spermidine (Fig. 8), two polyamines that help protect nucleic acids by scavenging ROS (Chol Ha et al., 1998). The protective role of polyamines against ROS, and the observation that ribosomes bind virtually all the intracellular spermidine (Davis et al., 1992), might also help explain the results obtained by Davis et al. (1986), who found that $E$. coli cells extensively degrade their ribosomes and die at the onset of $\mathrm{P}_{i}$ starvation. Indeed, the strain (D10) used by these authors was $\mathrm{Met}^{-}$and, hence, might produce reduced amounts of spermidine. This idea is supported by the fact that many spontaneous met $K$ mutations cause methionine auxotrophy and dramatically reduce $S$-adenosylmethionine synthetase activity (Satishchandran et al., 1990); a defect in metK expression and, hence, in spermidine synthesis might account for the exceptional sensitivity of strain D10 to $P_{1}$ starvation when the aggression to ribosomes by ROS is high. Taken together, these data support the idea that $E$. coli can normally survive starvation for $\mathrm{P}_{i}$ despite the maintenance of an aerobic metabolism, because of efficient protections against ROS provided notably by the synthesis of polyamines, and by the enhanced expression of the RpoS and LexA regulons.

Besides RpoS and LexA, we show that H-NS also plays a key role in $\mathrm{P}_{\mathrm{i}}$-starved cells. First of all, it should be noted that the intracellular concentration of a predominant isoform of $\mathrm{H}$-NS is increased about fourfold at the onset of $P_{i}$ starvation (VanBogelen et al., 1996) while DNA concentration is increased by about $20 \%$ (P. L. Moreau, unpublished results), which suggests that the ratio of $\mathrm{H}$-NS to DNA and, thus, the activity of H-NS may be significantly increased in $\mathrm{P}_{\mathrm{i}}$-starved cells. Our results indicate that a role of $\mathrm{H}-\mathrm{NS}$ is to maintain a rapid metabolism of glucose to acetate in $\mathrm{P}_{\mathrm{i}}$-starved cells. How could H-NS affect such a metabolism? Recent data indicate that in growing bacteria H-NS is required for the synthesis of glycolytic enzymes including the AceF and Lpd subunits of the acrobic PDH complex encoded by the aceEF/lpd operon (Smith \& Neidhardt, 1983; Quail et al., 1994; Laurent-Winter et al., 1997). A simple interpretation of our results is therefore that H-NS may also stimulate, directly or indirectly, the synthesis of these enzymes in $\mathrm{P}_{\mathrm{i}}$-starved cells, thereby increasing the activity of the aerobic PDH complex. Moreover, our results indicate that $\mathrm{H}-\mathrm{NS}$ is required for the degradation of arginine by the arginine decarboxylase SpeA-initiated pathway, which suggests that $\mathrm{H}-\mathrm{NS}$ may somehow enhance SpeA activity. Interestingly, it has been shown that $\mathrm{H}$-NS inhibits the expression of the other arginine decarboxylase, encoded by adiA, that is expressed under anaerobic conditions (Shi et al., 1993), which further supports the idea that H-NS may generally favour aerobic versus anaerobic catabolic processes in $\mathrm{P}_{\mathrm{i}}$ starved cells.

In contrast to the complete degradation of arginine and glucose that takes place in $h_{n s}{ }^{+}$cells starved for $\mathrm{P}_{i}$, the degradation of threonine occurred inefficiently, and threonine could be excreted to the culture medium. This surprising result is, however, in good agreement with the fact that, in growing bacteria, H-NS inhibits the expression of the $k b l / t d h$ operon encoding enzymes that initiate threonine degradation (Landgraf et al., 1994; Reitzer, 1996). In P ${ }_{\text {i }}$-starved cells, a possible role for this $\mathrm{H}-\mathrm{NS}$ inhibitory effect may be to trigger the synthesis of homoserine lactone, an activator of RpoS that is thought to be produced through the feedback inhibition by threonine of enzymes in the threonine biosynthetic pathway (Huisman \& Kolter, 1994) (Fig. 8). In the same view, it should be noted that the degradation of glucose to acetate may also enhance the activity of RpoS in two different ways, through a decrease in the intracellular concentration of UDP-glucose, an inhibitor of RpoS activity (Böhringer et al., 1995), and through an increase in the intracellular concentration of acetate, an activator of the RNA polymerase-RpoS $\left(\mathrm{E}^{\mathrm{s}}\right)$ holoenzyme (Ding et al., 1995). Therefore, in $\mathrm{P}_{\mathrm{i}}$-starved cells, a role of $\mathrm{H}$ NS may be to increase the activity of RpoS, whereas HNS somehow decreases the cellular concentration of RpoS in exponentially growing cells, an inhibiting effect that disappears, however, when cells enter stationary phase (Barth et al., 1995). In sum, the present work suggests that H-NS plays two complementary roles in $P_{i}$-starved cells: it helps maintain an aerobic metabolism and, thus, a high level of energy at least while glucose is in excess, and it increases the cellular defences against ROS that are then produced by increasing RpoS activity.

\section{ACKNOWLEDGEMENTS}

We wish to thank George N. Bennett, Winfried Boos, Erhard Bremer, Michael Cashel, Regine Hengge-Aronis, Richard Kolodner, Roberto Kolter, Robert G. Lloyd, Bénédicte Michel, Takeshi Mizuno, Emanuel J. Murgola, Frances T. Pagel, Lawrence J. Reitzer, Hideo Shinagawa, Joan L. Slonczewski, Graham C. Walker and Malcolm E. Winkler for providing bacterial strains, and Marc Chippaux for critical reading of the manuscript. This research was supported by the Association pour la Recherche sur le Cancer and by the Fondation pour la Recherche Médicale.

\section{REFERENCES}

Altuvia, S., Almirón, M., Huisman, G., Kolter, R. \& Storz, G. (1994). The $d p s$ promoter is activated by $O x y R$ during growth and by $\mathrm{IHF}$ and $\sigma^{*}$ in stationary phase. Mol Microbiol 13, 265-272.

Anderson, D. G. \& Kowalczykowski, S. C. (1998), Reconstitution of an $\$ O S$ response pathway: derepression of transcription in response to DNA breaks. Cell 95, 975-979.

Asai, T., Bates, D. B. \& Kogoma, T. (1994). DNA replication triggered by double-stranded breaks in E. coli: dependence on homologous recombination functions. Cell 78, 1051-1061.

Atlung, T. \& Ingmer, H. (1997). H-NS: a modulator of environmentally regulated gene expression. Mol Microbiol 24, 7-17.

Bachmann, B. J. (1996). Derivations and genotypes of some mutant derivatives of Escherichia coli K-12. In Escherichia coli and Salmonella: Cellular and Molecular Biology, pp. 2460-2488. Edited by F. C. Neidhardr and others. Washington, DC: American Society for Microbiology. 
Barth, M., Marschall, C., Muffler, A., Fischer, D. \& HenggeAronis, R. (1995). Role for the histone-like protein H-NS in growth phase-dependent and osmotic regulation of $\sigma^{\mathrm{s}}$ and many $\sigma^{s}$-dependent genes in Eschericbia coli. J Bacteriol 177, 3455-3464.

Blanar, M. A., Sandler, S. J., Armengod, M.-E., Ream, L. W. \& Clark, A. J. (1984). Molecular analysis of the recF gene of Escherichia coli. Proc Natl Acad Sci USA 81, 4622-4626.

Böck, A. \& Sawers, G. (1996). Fermentation. In Escherichia coli and Salmonella: Cellular and Molecular Biology, pp. 262-282. Edited by F.C. Neidhardt and others. Washington, DC: American Society for Microbiology.

Böhringer, J., Fischer, D., Mosler, G. \& Hengge-Aronis, R. (1995). UDP-glucose is a potential intracellular signal molecule in the control of expression of $\sigma^{\mathrm{s}}$ and $\sigma^{\mathrm{s}}$-dependent genes in Escherichia coli. J Bacteriol 177, 413-422.

Brawn, M. K. \& Fridovich, I. (1985). Increased superoxide radical production evokes inducible DNA repair in Escherichia coli. J Biol Chem 260, 922-925.

Chang, Y.-Y., Wang, A.-Y. \& Cronan, J. E., Jr (1994). Expression of Escherichia coli pyruvate oxidase (PoxB) depends on the sigma factor encoded by the rpoS $(k a t F)$ gene. Mol Microbiol 11, $1019-1028$

Chol Ha, H., Sirisoma, N. S., Kuppusamy, P., Zweier, J. L., Woster, P. M. \& Casero, R. A. (1998). The natural polyamine spermine functions directly as a free radical scavenger. Proc Natl Acad Sci USA 95, 11140-11145.

Cox, M. M. (1997). Recombinational crossroads: eukaryotic enzymes and the limits of bacterial precedents. Proc Natl Acad Sci USA 94, 11764-11766.

Davis, B. D., Luger, S. M. \& Tai, P. C. (1986). Role of ribosome degradation in the death of starved Escherichia coli cells. $J$ Bacteriol 166, 439-445.

Davis, R. H., Morris, D. R. \& Coffino, P. (1992). Sequestered end products and enzyme regulation: the case of ornithine decarboxylase. Microbiol Rev 56, 280-290.

Demple, B. \& Harrison, L. (1994). Repair of oxidative damage to DNA : enzymology and biology. Annu Rev Biochem 63, 915-948.

Dersch, P., Kneip, S. \& Bremer, E. (1994). The nucleoid-associated DNA-binding protein $\mathrm{H}-\mathrm{NS}$ is required for the efficient adaptation of Escherichia coli K-12 to cold environment. Mol Gen Genet 245, 255-259.

Ding, Q., Kusano, S., Villarejo, M. \& Ishihama, A. (1995). Promoter selectivity control of Escherichia coli RNA polymerase by ionic strength : differential recognition of osmoregulated promoters by $\mathrm{E} \sigma^{\mathrm{D}}$ and $\mathrm{E} \sigma^{\mathrm{s}}$ holoenzymes. Mol Microbiol 16, 649-656.

Dri, A.-M. \& Moreau, P. L. (1993). Phosphate starvation and low temperature as well as ultraviolet irradiation transcriptionally induce the Escherichia coli LexA-controlled gene sfiA. Mol Microbiol 8, 697-706.

Dri, A.-M. \& Moreau, P. L. (1994). Control of the LexA regulon by $\mathrm{pH}$ : evidence for a reversible inactivation of the LexA repressor during the growth cycle of Escherichia coli. Mol Microbiol 12, 621-629.

Eggertsson, G. \& Söll, D. (1988). Transfer ribonucleic acidmediated suppression of termination codons in Escherichia coli. Microbiol Rev 52, 354-374.

El-Mansi, E. M. T. \& Holms, W. H. (1989). Control of carbon flux to acetate excretion during growth of Escherichia coli in batch and continuous cultures. J Gen Microbiol 135, 2875-2883.

Gennis, R. B. \& Stewart, V. (1996). Respiration. In Escherichia coli and Salmonella: Cellular and Molecular Biology, pp. 217-261.
Edited by F.C. Neidhardt and others. Washington, DC: American Society for Microbiology.

Gentry, D. R., Hernandez, V. J., Nguyen, L. H., Jensen, D. B. \& Cashel, M. (1993). Synthesis of the stationary-phase sigma factor $\sigma^{\mathrm{s}}$ is positively regulated by ppGpp. J Bacteriol $\mathbf{1 7 5}, 7982-7989$.

Glansdorff, N. (1996). Biosynthesis of arginine and polyamines. In Escherichia coli and Salmonella: Cellular and Molecular Biology, pp. 408-433. Edited by F. C. Neidhardt and others. Washington, DC: American Society for Microbiology.

González-Flecha, B. \& Demple, B. (1995). Metabolic sources of hydrogen peroxide in aerobically growing Escherichia coli. J Biol Chem 270, 13681-13687.

González-Flecha, B. \& Demple, B. (1997). Homeostatic regulation of intracellular hydrogen peroxide concentration in aerobically growing Escherichia coli. J Bacteriol 179, 382-388.

Gort, A. S. \& Imlay, J. A. (1998). Balance between endogenous superoxide stress and antioxidant defenses. J Bacteriol 180, 1402-1410.

Guest, J. R. (1992). Oxygen-regulated gene expression in Escherichia coli. J Gen Microbiol 138, 2253-2263.

Hengge-Aronis, R. (1996). Regulation of gene expression during entry into stationary phase. In Escherichia coli and Salmonella: Cellular and Molecular Biology, pp. 1497-1512. Edited by F. C. Neidhardt and others. Washington, DC: American Society for Microbiology.

Henle, E. S. \& Linn, S. (1997). Formation, prevention, and repair of DNA damage by iron/hydrogen peroxide. J Biol Chem 272, 19095-19098.

Henle, E. S., Han, Z., Tang, N., Rai, P., Luo, Y. \& Linn, S. (1999). Sequence-specific DNA cleavage by $\mathrm{Fe}^{2+}$-mediated Fenton reaction has possible biological implications. J Biol Chem 274, 962-971.

Higgins, C. F., Dorman, C. J., Stirling, D. A., Waddell, L., Booth, I. R., May, G. \& Bremer, E. (1988). A physiological role for DNA supercoiling in the osmotic regulation of gene expression in $S$. typhimurium and E. coli. Cell 52, 569-584.

Holms, H. (1996). Flux analysis and control of the central metabolic pathways in Escherichia coli. FEMS Microbiol Rev 19, 85-116.

Huisman, O. \& D'Ari, R. (1983). Effect of suppressors of SOSmediated filamentation on sfiA operon expression in Escherichia coli. J Bacteriol 153, 169-175.

Huisman, G. W. \& Kolter, R. (1994). Sensing starvation: a homoserine lactone-dependent signaling pathway in Escherichia coli. Science 265, 537-539.

Keyer, K. \& Imlay, J. A. (1996). Superoxide accelerates DNA damage by elevating free-iron levels. Proc Natl Acad Sci USA 93, 13635-13640.

Kolodner, R., Fishel, R. A. \& Howard, M. (1985). Genetic recombination of bacterial plasmid DNA : effect of RecF pathway mutations on plasmid recombination in Escherichia coli. J Bacteriol 163, 1060-1066.

Kowalczykowski, S. C., Dixon, D. A., Eggleston, A. K., Lauder, S.D. \& Rehrauer, W. M. (1994). Biochemistry of homologous recombination in Escherichia coli. Microbiol Rev 58, 401-465.

Kreutzer, D. \& Essigmann, J. M. (1998). Oxidized, deaminated cytosines are a source of $\mathrm{C} \rightarrow \mathrm{T}$ transitions in vivo. Proc Natl Acad Sci USA 95, 3578-3582.

Krueger, J. H., Elledge, S. J. \& Walker, G. C. (1983). Isolation and characterization of $\operatorname{Tn} 5$ insertion mutations in the lexA gene of Escherichia coli. I Bacteriol 153, 1368-1378. 
Landgraf, J. R., Levinthal, M. \& Danchin, A. (1994). The role of HNS in one carbon metabolism. Biochimie 76, 1063-1070.

Lange, R. \& Hengge-Aronis, R. (1991). Identification of a central regulator of stationary-phase gene expression in Escherichia coli. Mol Microbiol 5, 49-59.

Laurent-Winter, C., Ngo, S., Danchin, A. \& Bertin, P. (1997). Role of Escherichia coli histone-like nucleoid-structuring protein in bacterial metabolism and stress response. Identification of targets by two-dimensional electrophoresis. Eur J Biochem 244, 767-773.

Lloyd, R. G. \& Low, K. B. (1996). Homologous recombination. In Escherichia coli and Salmonella: Cellular and Molecular Biology, pp. 2236-2255. Edited by F. C. Neidhardt and others. Washington, DC: American Society for Microbiology.

Lloyd, R. G., Buckman, C. \& Benson, F. E. (1987). Genetic analysis of conjugational recombination in Escherichia coli K12 strains deficient in RecBCD enzyme. J Gen Microbiol 133, 2531-2538.

Lynch, A. S. \& Lin, E. C. C. (1996). Response to molecular oxygen. In Escherichia coli and Salmonella: Cellular and Molecular Biology, pp. 1526-1538. Edited by F. C. Neidhardt and others. Washington, DC: American Society for Microbiology.

Mandal, T. N., Mahdi, A. A., Sharples, G. J. \& Lloyd, R. G. (1993). Resolution of Holliday intermediates in recombination and DNA repair: indirect suppression of $r u \nu A, r u \nu B$, and $r u \nu C$ mutations. J Bacteriol 175, 4325-4334.

Miller, J. H. (1972). Experiments in Molecular Genetics. Cold Spring Harbor, NY: Cold Spring Harbor Laboratory.

Moreau, P. L. (1987). Effects of overproduction of single-stranded DNA-binding protein on RecA protein-dependent processes in Escherichia coli. J Mol Biol 194, 621-634.

Moreau, P. L. (1988). Overproduction of single-stranded-DNAbinding protein specifically inhibits recombination of UVirradiated bacteriophage DNA in Escherichia coli. J Bacteriol 170, 2493-2500.

Mount, D. W. \& Kosel, C. (1975). Ultraviolet light-induced mutation in UV-resistant, thermosensitive derivatives of lex $A^{-}$ strains of Escherichia coli K-12. Mol Gen Genet 136, 95-106.

Neidhardt, F. C., Bloch, P. L. \& Smith, D. (1974). Culture medium for enterobacteria. J Bacteriol 119, 736-747.

Neidhardt, F. C., Bloch, P. L., Pedersen, S. \& Reeh, S. (1977). Chemical measurement of steady-state levels of ten aminoacyltransfer ribonucleic acid synthetases in Escherichia coli. J Bacteriol 129, 378-387.

Nyström, T. (1994). The glucose-starvation stimulon of Escherichia coli: induced and repressed synthesis of enzymes of central metabolic pathways and role of acetyl phosphate in gene expression and starvation survival. Mol Microbiol 12, 833-843.

Nyström, T., Larsson, C. \& Gustafsson, L. (1996). Bacterial defense against aging: role of the Escherichia coli ArcA regulator in gene expression, readjusted energy flux and survival during stasis. EMBO 15, 3219-3228.

Ossanna, N. \& Mount, D. W. (1989). Mutations in $u v r D$ induce the SOS response in Escherichia coli. J Bacteriol 171, 303-307.

Prather, N. E., Mims, B. H. \& Murgola, E. J. (1983). $\sup G$ and $s u p L$ in Escherichia coli code for mutant lysine tRNAs. Nucleic Acids Res 23, 8283-8286.

Quail, M. A., Haydon, D. J. \& Guest, J. R. (1994). The $p d b R$ aceEF-lpd operon of Escherichia coli expresses the pyruvate dehydrogenase complex. Mol Microbiol 12, 95-104.

Rao, N. N., Roberts, M. F., Torriani, A. \& Yashphe, J. (1993). Effect of $g l p T$ and $g l p D$ mutations on expression of the phoA gene in Escherichia coli. J Bacteriol 175, 74-79.
Reitzer, L. J. (1996). Sources of nitrogen and their utilization. In Escherichia coli and Salmonella: Cellular and Molecular Biology, pp. 380-390. Edited by F. C. Neidhardt and others. Washington, DC: American Society for Microbiology.

Rupp, W. D. (1996). DNA repair mechanisms. In Escherichia coli and Salmonella: Cellular and Molecular Biology, pp. 2277-2294. Edited by F.C. Neidhardt and others. Washington, DC: American Society for Microbiology.

Sak, B. D., Eisenstark, A. \& Touati, D. (1989). Exonuclease III and the catalase hydroperoxidase II in Escherichia coli are both regulated by the katF gene product. Proc Natl Acad Sci USA 86, 3271-3275.

Sassanfar, M. \& Roberts, J. W. (1990). Nature of the SOS-inducing signal in Escherichia coli. The involvement of DNA replication. $J$ Mol Biol 212, 79-96.

Satishchandran, C., Taylor, J. C. \& Markham, G. D. (1990). Novel Escherichia coli K-12 mutants impaired in $S$-adenosylmethionine synthesis. J Bacteriol 172, 4489-4496.

Schneider, B. L., Kiupakis, A. K. \& Reitzer, L. J. (1998). Arginine catabolism and the arginine succinyltransferase pathway in Escherichia coli. J Bacteriol 180, 4278-4286.

Sharples, G. J., Benson, F. E., Illing, G. T. \& Lloyd, R. G. (1990). Molecular and functional analysis of the ruv region of Escherichia coli K-12 reveals three genes involved in DNA repair and recombination. Mol Gen Genet 221, 219-226.

Shi, X., Waasdorp, B. C. \& Bennett, G. N. (1993). Modulation of acid-induced amino acid decarboxylase gene expression by $h n s$ in Escherichia coli. J Bacteriol 175, 1182-1186.

Singer, M., Baker, T. A., Schnitzler, G. \& 7 other authors (1989). A collection of strains containing genetically linked alternating antibiotic resistance elements for genetic mapping of Escherichia coli. Microbiol Rev 53, 1-24.

Smith, M. W. \& Neidhardt, F. C. (1983). 2-Oxoacid dehydrogenase complexes of Escherichia coli: cellular amount and pattern of synthesis. J Bacteriol 156, 81-88.

Stim-Herndon, K. P., Flores, T. M. \& Bennett, G. N. (1996). Molecular characterization of adiY, a regulatory gene which affects expression of the biodegradative acid-induced arginine decarboxylase gene (adiA) of Escherichia coli. Microbiology 142, 1311-1320.

Umezu, K. \& Kolodner, R. D. (1994). Protein interactions in genetic recombination in Escherichia coli. J Biol Chem 269, 30005-30013.

VanBogelen, R. A., Olson, E. R., Wanner, B. L. \& Neidhardt, F. C. (1996). Global analysis of proteins synthesized during phosphorus restriction in Escherichia coli. J Bacteriol 178, $4344-4366$.

Vaughan, M. (1997). Minireview Prologue. Oxidative modification of macromolecules minireview series. J Biol Chem 272, 18513.

Visick, J. E. \& Clarke, S. (1997). RpoS- and OxyR-independent induction of HPI catalase at stationary phase in Escherichia coli and identification of rpoS mutations in common laboratory strains. J Bacteriol 179, 4158-4163.

Walker, G. C. (1996). The SOS response of Escherichia coli. In Escherichia coli and Salmonella: Cellular and Molecular Biology, pp. 1400-1416. Edited by F. C. Neidhardt and others. Washington, DC: American Society for Microbiology.

Wanner, B. L. (1986). Novel regulatory mutants of the phosphate regulon in Escherichia coli K-12. J Mol Biol 191, 39-58.

Willis, D. K., Uhlin, B. E., Amini, K. S. \& Clark, A. J. (1981). 
Physical mapping of the $s r l$ recA region of Escherichia coli: analysis of Tn10 generated insertions and deletions. Mol Gen Genet 183, 497-504.

Yamada, H., Yoshida, T., Tanaka, K., Sasakawa, C. \& Mizuno, T. (1991). Molecular analysis of the Escherichia coli hns gene encoding a DNA-binding protein, which preferentially recognizes curved DNA sequences. Mol Gen Genet 230, 332-336.
Zambrano, M. M., Siegele, D. A., Almirón, M., Tormo, A. \& Kolter, R. (1993). Microbial competition: Escherichia coli mutants that take over stationary phase cultures. Science 259, 1757-1760.

Received 6 January 1999; revised 19 March 1999; accepted 26 March 1999. 